\title{
Michael Acceptor Approach to the Design of New Salvinorin A- based High Affinity Ligands for the Kappa-Opioid Receptor
}

\author{
Prabhakar R. Polepally ${ }^{a}$, Krzysztof Huben ${ }^{a, d}$, Eyal Vardy ${ }^{b}$, Vincent Setola ${ }^{b}$, Philip D. \\ Mosier $^{\mathrm{c}}$, Bryan L. Roth ${ }^{\mathrm{b}}$, and Jordan K. Zjawiony ${ }^{\mathrm{a},{ }^{*}}$
}

aDepartment of Pharmacognosy and Research Institute of Pharmaceutical Sciences, School of Pharmacy, University of Mississippi, University, MS 38677-1848, USA bepartment of Pharmacology, School of Medicine and Division of Medicinal Chemistry and Natural Products, School of Pharmacy, NIMH Psychoactive Drug Screening Program, University of North Carolina, Chapel Hill, NC 27599, USA 'Department of Medicinal Chemistry and Institute for Structural Biology and Drug Discovery, Virginia Commonwealth University, Richmond, VA 23298-0540, USA IInstitute of Organic Chemistry, Technical University of Lodz, 90-924 Lodz, Poland

\begin{abstract}
The neoclerodane diterpenoid salvinorin A is a major secondary metabolite isolated from the psychoactive plant Salvia divinorum. Salvinorin A has been shown to have high affinity and selectivity for the $\kappa$-opioid receptor (KOR). To study the ligand-receptor interactions that occur between salvinorin A and the KOR, a new series of salvinorin A derivatives bearing potentially reactive Michael acceptor functional groups at $\mathrm{C}-2$ was synthesized and used to probe the salvinorin A binding site. The $\kappa-, \delta$-, and $\mu$-opioid receptor (KOR, DOR and MOR, respectively) binding affinities and KOR efficacies were measured for the new compounds. Although none showed wash-resistant irreversible binding, most of them showed high affinity for the KOR, and some exhibited dual affinity to KOR and MOR. Molecular modeling techniques based on the recently-determined crystal structure of the KOR combined with results from mutagenesis studies, competitive binding, functional assays and structure-activity relationships, and previous salvinorin A-KOR interaction models were used to identify putative interaction modes of the new compounds with the KOR and MOR.
\end{abstract}

\footnotetext{
(C) 2014 Elsevier Masson SAS. All rights reserved.

Corresponding Author address: Professor Jordan K. Zjawiony, Department of Pharmacognosy, School of Pharmacy, University of Mississippi, University, MS 39677, Tel.: +1 662-915-7290, Fax: +1 662-915-6975, jordan @ olemiss.edu.

Supporting information

Scatter plot of $\mathrm{p} K_{\mathrm{i}}$ vs. $\mathrm{pIC} 50$ at KOR for salvinorin A and tested analogs, ${ }^{1} \mathrm{H},{ }^{13} \mathrm{C}$ NMR spectra and chromatographic (HPLC) data for synthesized compounds $\mathbf{4 a - 4 h}$ and $\mathbf{5 a}-\mathbf{5 n}$ are presented in the Supporting Information.

Conflict of interest statement

The authors declare that there are no conflicts of interest.

Publisher's Disclaimer: This is a PDF file of an unedited manuscript that has been accepted for publication. As a service to our customers we are providing this early version of the manuscript. The manuscript will undergo copyediting, typesetting, and review of the resulting proof before it is published in its final citable form. Please note that during the production process errors may be discovered which could affect the content, and all legal disclaimers that apply to the journal pertain.
} 


\section{Keywords}

Salvinorin A and B; Michael acceptor-type ligands; kappa; delta; mu opioid receptors; molecular modeling

\section{Introduction}

The neoclerodane diterpenoid salvinorin A (1; Figure 1) is a major metabolite isolated from the leaves of Salvia divinorum [1]. It is a highly selective K-opioid receptor (KOR) agonist and is the most potent naturally-occurring hallucinogen [2]. It gained significant scientific interest as the only non-nitrogenous KOR agonist with no apparent structural similarity to other ligands. This has encouraged several research groups to study the structure-activity relationships of $\mathbf{1}$, and a plethora of salvinorin A derivatives has been synthesized over the past decade [3-8]. Some of these analogues exhibit interesting pharmacological profiles from full KOR agonist to partial DOR or MOR agonist and antagonists. However, most of these derivatives displayed decreased affinity or even no affinity for the KOR. Our current objective was to use the knowledge about salvinorin A-KOR interactions to rationally design salvinorin A derivatives with different pharmacological profiles and therapeutic potential. In the course of our work on the molecular mechanism of interaction of salvinorin A with the KOR, we reported the irreversible binding of 22-thiocyanatosalvinorin A (2) (Fig. 1) with the sulfhydryl group of $\mathrm{C} 315$ at the $\kappa$-opioid receptor $[9,10]$. Previous results using the KOR model and crystal structure to predict the mode of binding of $\mathbf{2}$, combined with mass spectrometric analysis of the enzymatically digested KOR-2 complex show that Cys $315_{7.35}$ in the orthosteric binding site is an anchoring amino acid for compounds bearing a thioltrapping group $[9,10]$. We therefore designed a series of salvinorin B-based $(\mathbf{3})$ a, $\beta$ unsaturated esters at the $\mathrm{C}-2$ position with diverse stereoelectronic properties and whose reactive nucleophilic center positions approximately matched those of the previouslyreported thiol-trapping analogs [10] (Schemes 1 and 2).

In this work we describe the synthesis of various potential Michael acceptor-type derivatives of salvinorin A and their affinity to KOR, as well as molecular models of their interaction with the receptor. Michael acceptors are capable of forming irreversible bonds with biological macromolecules such as proteins or DNA [11-15]. Thus, the ability of salvinorin A-derived Michael acceptors to form covalent bonds may be advantageous for probing the affinity to the KOR. Considering the fact that Michael acceptors may also react reversibly with nucleophiles [15-19], such compounds may provide potential drug candidates for CNS disorders. Herein, we report the synthesis of a new series of potential Michael acceptor-type salvinorin A derivatives modified at $\mathrm{C}-2$, a position that has been found to be crucial for a high-affinity binding to the KOR [3]. Among the compounds synthesized and tested were a set of cinnamic acid derivatives, which were selected with the knowledge that salvinorin derivatives bearing an aromatic substituent at the $\mathrm{C}-2$ position (the most noteworthy of which is 2-O-benzoylsalvinorin B or herkinorin[20]) exhibit a marked change in the compounds' pharmacological profile compared to salvinorin A; in particular, these compounds tended to exhibit reduced affinity for KOR and increased affinity for MOR [3]. At the same time we hypothesized that adding a conjugated bond to the aromatic system 
might further increase MOR affinity as the introduction of alkene moieties at the C-2 position showed a similar shift in pharmacological profile [21].

\section{Results and discussion}

\subsubsection{Chemistry}

The starting material, salvinorin A (1), was isolated from commercially available dried leaves of Salvia divinorum, and then converted to salvinorin B (3) in high yield [22]. The reaction of $\mathbf{3}$ with appropriate acryloyl chlorides under basic conditions afforded $\mathbf{4 a} \mathbf{a} \mathbf{- 4 h}$, and with various substituted cinnamic acids the corresponding $\mathbf{5 a - 5 n}$ derivatives as shown in Schemes 1 and 2 .

The reaction of $\mathbf{3}$ with acryloyl chloride or methacryloyl chloride in dry DCM in the presence of triethylamine afforded $\mathbf{4 a}$ or $\mathbf{4 b}[21]$ in 73 and $70 \%$ yield, respectively. The ${ }^{1} \mathrm{H}$ NMR data of acrylate $4 \mathbf{a}$ displayed typical acrylate protons as a doublet of doublets at $\delta 6.20$ $(J=8.0,16.4 \mathrm{~Hz})$, and two doublets at $\delta 6.49(J=16.4 \mathrm{~Hz})$, and $5.93(J=8.0 \mathrm{~Hz})$. The corresponding data of $\mathbf{4 b}[21]$ confirmed the presence of the methacrylate group [ $\delta 6.23(1 \mathrm{H}$, d, $J=1.6 \mathrm{~Hz}), 5.68(1 \mathrm{H}, \mathrm{d}, J=1.6 \mathrm{~Hz})$, and $1.99(3 \mathrm{H}, \mathrm{s})]$. Interestingly, when 3 was subjected to 3,3-dimethylacryloyl chloride (senecioyl chloride) under the same conditions it yielded two isomers $\mathbf{4 c}$ and $\mathbf{4 d}$ (Scheme 1). Compound $\mathbf{4 c}$, the anticipated salvinorin 3,3dimethylacrylate displayed characteristic ${ }^{1} \mathrm{H}$ - and ${ }^{13} \mathrm{C}$ NMR signals at $\delta 5.80[1 \mathrm{H}, \mathrm{s}$, $\left(\mathrm{CH}_{3}\right)_{2} \mathrm{C}=\mathrm{CH}-\mathrm{CO}_{2}$ ], 2.17 and 1.92 [each $3 \mathrm{H}$, s, $\left(\mathrm{CH}_{3}\right)_{2} \mathrm{C}=\mathrm{CH}-\mathrm{CO}_{2}-$ ], $\delta 114.85\left(\mathrm{C}-2^{\prime}\right), 27.35$ and $20.46\left(\right.$ each $\left.\mathrm{CH}_{3}\right)$. The second product $(\mathbf{4 d})$ proved to be the non-conjugated isomer of 4c. Its ${ }^{1} \mathrm{H}$ NMR spectrum displayed the side chain protons at $\delta 3.15\left(\mathrm{H}-2^{\prime}, \mathrm{s}\right), \delta 1.85\left(\mathrm{CH}_{3}\right.$, s), and the olefinic methylene protons at $\delta 4.90$ and 4.95 (both s). ${ }^{13} \mathrm{C}$ NMR experiments confirmed the $\mathrm{C}-2^{\prime}$ and $\mathrm{C}-4^{\prime}$ methylene carbons at $\delta 43.20$ and 115.17 , and the $\mathrm{C}-3^{\prime}$ methyl carbon at $\delta 22.46$. The formation of conjugated and non-conjugated isomers in esterification of alcohols with 3,3-dimethylacryloyl chloride in the presence of triethylamine was observed earlier [23, 24]. The elimination-addition and competitive substitution mechanisms are responsible for the formation of both isomers. In the first case the reaction proceeds through the formation of a ketene intermediate, in the second case through the acyl quaternary ammonium intermediate. Participation of the elimination-addition mechanism was further supported by using an excess of triethylamine. Changing the excess of $\mathrm{Et}_{3} \mathrm{~N}$ from 1.5 to 3.0 eq altered the ratio of conjugated $(\mathbf{4 c})$ to non-conjugated $(\mathbf{4 d})$ product from 1:4 to 1:1. Similarly, a mixture of conjugated and non-conjugated isomers $4 \mathbf{e}-\mathbf{4 h}$ were obtained in the reaction of $\mathbf{3}$ with crotonyl- and 2,3-dimethylacryloyl chloride (Scheme 1). Salvinorin B (3) treated with aromatic and heterocyclic $\alpha, \beta$-unsaturated carboxylic acids in the presence of DCC and DMAP yielded corresponding products $\mathbf{5 a}-\mathbf{5 n}$ in good yields (6192\%), e.g., reaction of $\mathbf{3}$ with trans-cinnamic acid at room temperature afforded 2-Ocinnamoylsalvinorin B (5a) in 92\% yield (Scheme 2). The ${ }^{1} \mathrm{H}$ - and ${ }^{13} \mathrm{C}$ NMR data of $\mathbf{5 a}$ showed the trans olefinic protons at $\delta 6.52$ and 7.75 (each d, $J=16.8 \mathrm{~Hz}$ ), and the $\mathrm{C}-2^{\prime}$ and C- $3^{\prime}$ olefinic carbons at $\delta 139.46$ and 143.64 , respectively.

To enhance our understanding of the binding mode between synthesized ligands and the receptor (reversible vs. irreversible labeling), we performed the model Michael addition 
reactions between acrylate derivative (4a) and thiols like cysteamine and $N$-acetylcysteine using the reported procedure [16]. Thus, $4 \mathbf{a}$ was dissolved in DMSO- $d_{6}$, the ${ }^{1} \mathrm{H}$ NMR spectrum was recorded (Figure $2 \mathrm{~b}$ ), and then two equivalents of cysteamine were added and the spectrum recorded after 5 min (Figure 2c). This spectrum showed the disappearance of the olefinic protons of the acrylate moiety. An aliquot of the solution was transferred to another vial, and diluted with $\mathrm{CDCl}_{3}(1: 15 \mathrm{v} / \mathrm{v})$. The ${ }^{1} \mathrm{H}$ NMR spectrum (Figure $2 \mathrm{~d}$ ) of this solution showed that the proton resonances of the olefinic system did not reappear, hence indicating the irreversible formation of the covalent thioether bond. Similar results were observed in the experiment with $\mathrm{N}$-acetylcysteine.

\subsubsection{Biological affinity and efficacy at opioid receptors}

The synthesized analogues (4a-4h and 5a-5n) were evaluated for $\kappa-, \delta-, \mu$ - opioid receptor binding affinities at the NIMH-sponsored Psychoactive Drug Screening Program, University of North Carolina at Chapel Hill. The assays were conducted according to the procedure described earlier $[2,25]$ and the results are summarized in Table 1. Interestingly, none of the compounds exhibited wash-resistant irreversible binding at KOR as was previously observed for the 22-thiocyanatosalvinorin A analog RB-64 [10]. There may be several reasons for this. First, although the acrylate 4a reacted readily with small thiols in solution (vide supra), the relative position and orientation of the electrophilic center in the acceptor moiety and the $\mathrm{C} 315$ sulfur nucleophile in the bound receptor-ligand complex may preclude nucleophilic attack. The relatively rigid and planar character of the acrylate moiety differs from that of the more flexible 22- thiocyanato moiety of RB-64 in which there are two rotatable bonds between the carbonyl carbon atom and the thiocyanate sulfur atom. Second, many of the acrylate derivatives are substituted at the electrophilic carbon; these substituents may bind in separate subpockets of the receptor (vide infra), which may also serve to orient the acceptor moiety away from the nucleophilic sulfur atom. Third, the alkene moiety of the non-conjugated products $(\mathbf{4 d}, \mathbf{4 f}, \mathbf{4 h})$ may not be sufficiently reactive toward sulfur nucleophiles to form a covalent linkage. Fourth, the reversibility of the addition reaction may be too great to detect transient covalent linkages between receptor and ligand. Despite their non-reactivity, however, many of the compounds showed high affinity for KOR. The aliphatic conjugated and non-conjugated series of analogs $(\mathbf{4 a} \mathbf{a}-\mathbf{h})$ are all of similar size but with varying patterns of methyl group substitution and unsaturation; each showed significant affinity for the $\kappa$-opioid receptor. In the conjugated series, the acrylate derivative $\mathbf{4 a}$ had a 6fold reduced but still appreciable affinity at the $\kappa$-receptor as compared to $\mathbf{1}\left(K_{\mathrm{i}}=18.1 \mathrm{nM}\right.$ vs. $K_{\mathrm{i}}=2.9 \mathrm{nM}$ ) (Table 1). Previously published methacrylate derivative $\mathbf{4 b}$ also showed good affinity for the $\kappa$-receptor [21]. Owing to the presence of bulky methyl groups at the $a$ - and $\beta$-positions, the KOR affinities of $\mathbf{4} \mathbf{c}$ and $\mathbf{4 g}$ were reduced 21- and 8-fold, respectively, as compared to $\mathbf{4 a}$. The crotonate derivative $\mathbf{4 e}$, however, exhibited almost equal affinity as $\mathbf{4 a}\left(K_{\mathrm{i}}=25.3 \mathrm{nM}\right.$ vs. $\left.K_{\mathrm{i}}=18.1 \mathrm{nM}\right)$. Interestingly, non-conjugated derivatives $\mathbf{4 d}$ and $\mathbf{4 f}$ showed 3 - and 2 -fold increased affinities at the KOR, compared to acrylate derivative $4 \mathbf{a}\left(K_{\mathrm{i}}=6\right.$ and $10 \mathrm{nM}$, respectively, vs. $\left.K_{\mathrm{i}}=18.1 \mathrm{nM}\right)$. Again, derivative 4h having a methyl group a to the carbonyl had reduced affinity at the KOR as compared to $4 \mathbf{a}\left(K_{\mathrm{i}}=28.8 \mathrm{nM}\right.$ vs. $\left.K_{\mathrm{i}}=18.1 \mathrm{nM}\right)$. The results show that the non-conjugated series of analogues have higher binding KOR affinities than the corresponding conjugated series of compounds, and that C-a substitution results in lower affinity. This may emphasize the 
importance of the presence of an intervening methylene group that effectively separates the $\pi$-systems of the ester and alkene portions of the side chain over direct ester-alkene conjugation on the affinity to the KOR. Of note is the retention of high KOR selectivity of compounds $4 \mathbf{a}-\mathbf{4 h}$ with low or no affinity to the DOR and MOR, as observed for the smaller analog, salvinorin A [2].

The aromatic series of compounds $\mathbf{5 a - 5 n}$ generally displayed lower affinity for the KOR than the smaller conjugated compounds $\mathbf{4 a - c}, \mathbf{4 e}$ and $\mathbf{4 g}$. Interestingly, the unsubstituted cinnamate derivative 5a displayed dual affinity at the KOR and MOR, exhibiting 2- and 18fold increased affinity, respectively, compared to 4a. Compounds with electron withdrawing or donating substituents at different positions of the phenyl ring (5b-5l) showed reduced or no affinity at the KOR and no appreciable affinity for MOR or DOR. For the KOR, several trends could be identified. Substitution at the ortho position is tolerated more than substitution at the para position (compare $\mathbf{5 b}$ with $\mathbf{5 c}, \mathbf{5 h}$ with $\mathbf{5 i}$, and $\mathbf{5 j}$ with $\mathbf{5 k}$ ). The 2,5dimethoxy analog $\mathbf{5 d}$ exhibited a much lower affinity than the 2-methoxy analog $\mathbf{5 b}$, indicating that substitution at the meta position also adversely affects binding affinity. The electron-donating methoxy group is tolerated more than the electron-withdrawing nitro or trifluoromethyl groups (compare $\mathbf{5 b}$ with $\mathbf{5 h}$ and $\mathbf{5 j}$; also $\mathbf{5 c}$ with $\mathbf{5 i}$ and $\mathbf{5 k}$ ). The 3,4,5trimethoxy compound $\mathbf{5} \mathbf{f}$ showed no appreciable affinity for any of the three opioid receptors. Introduction of heteroaromatic ring moieties such as 3-pyridyl (5m) and 3thiophenyl (5n) groups resulted in a significant increase of the MOR and DOR affinities in comparison to all analogues in the substituted aromatic series, including the phenyl analog 5a. Intriguingly, substitution of the phenyl group with the isosteric 3-pyridyl group completely reverses the KOR-MOR selectivity profile, with analog $\mathbf{5 m}$ showing no affinity for KOR but with significant affinity for MOR $\left(K_{\mathrm{i}}=334 \mathrm{nM}\right)$. The isosteric thiophenyl derivative $5 \mathbf{n}$ also showed high MOR selectivity $\left(K_{\mathrm{i}}=18 \mathrm{nM}\right)$ but also had affinity for KOR $\left(K_{\mathrm{i}}=304 \mathrm{nM}\right)$ and DOR $\left(K_{\mathrm{i}}=228 \mathrm{nM}\right)$.

The efficacy of salvinorin A (1) and analogs $4 \mathbf{a}-\mathbf{h}$ and $\mathbf{5 a}-\mathbf{n}$ at the KOR was also evaluated using an assay that measures cAMP inhibition (Table 1). None of the analogs 4a-h or 5a-n were as efficacious as salvinorin $\mathrm{A}\left(\mathbf{1} ; \mathrm{IC}_{50}=0.36 \mathrm{nM}\right)$. Many of the tested analogs showed an inhibition level that was $\sim 100 \times$ less than that produced by $\mathbf{1}$, the most efficacious of which $\left(\mathbf{5 a} ; \mathrm{IC}_{50}=7 \mathrm{nM}\right)$ showed an inhibition level that was $20 \times$ lower than $\mathbf{1}$. The compounds showing the poorest efficacy $(\mathbf{5 f}, \mathbf{5 l}, \mathbf{5 m})$ also had no substantial affinity for the KOR. Although there was not a strong correlation between affinity and efficacy for the tested compounds (see Figure S1), those of the aromatic series (except 5a) tended to show efficacy similar to those of the non-conjugated series but with lower binding affinity. Interestingly, compound $\mathbf{4 a}$, whose binding affinity is only $6 \times$ less than $\mathbf{1}$, was $380 \times$ less efficacious.

\subsubsection{Molecular Modeling}

We have used the crystal structure of the KOR complexed with the antagonist JDTic (PDB $\mathrm{ID}=4 \mathrm{DJH}$ ) to model the interaction of various agonists with the receptor. Although technically in an inactive state, it has been shown that large-scale movements of amino acid residues in the orthosteric binding site of class A GPCRs are not requisite for activation of 
the receptor [26]. In addition, it has been found that virtual screening for ligands using inactive-state GPCRs can produces agonist leads (see for example Negri et al.) [27]. We have previously described a putative binding mode for salvinorin A representing an initial recognition mode based on an extensive amount of experimental data [9, 28]. This binding mode was reproduced in the current docking studies and is shown in Figure 3a. In the proposed binding mode, the fused tricyclic core is oriented toward TM2 and interacts primarily with the side chains of $\mathrm{V} 108^{2.53}, \mathrm{~T} 111^{2.56}, \mathrm{Q} 115^{2.60}, \mathrm{~V} 118^{2.63}, 134^{3.28}, 135^{3.29}$ and $\mathrm{D} 138^{3.32}$, which form a highly complementary stereoelectronic binding site for the salvinorin core structure (numbers in parentheses indicate Ballesteros-Weinstein indexes [29]). The furanyl moiety interacts with $\mathrm{V} 118^{2.63}, \mathrm{~W} 124^{\mathrm{EL} 1}$ and $\mathrm{C} 210^{\mathrm{EL} 2}$, and in a slightly different pose, may also possibly form hydrogen bonds with Y313 ${ }^{7.36 .9}$ The C4 methyl ester is situated in a small pocket formed by $\mathrm{V} 108^{2.53}$, T111 2.56 , W2 $287^{6.48}$ and $\mathrm{Y} 320^{7.43}$ and engages in hydrogen bonding interactions with $\mathrm{T} 111^{2.56}$ and $\mathrm{Y} 320^{7.43}$. The $\mathrm{C} 2$ acetoxy group engages a small subpocket delineated by D138 $8^{3.32}$, Y139 3.33 and M142 ${ }^{3.36}$.

For each of the compounds $\mathbf{4 a - h}$ and $\mathbf{5 a}-\mathbf{n}$, a docked pose analogous to $\mathbf{1}$ was obtained for the KOR, although the various substituents at the $\mathrm{C} 2$ position bound in somewhat different orientations. These varying orientations were able to provide insights regarding the possible interaction modes of the compounds at the KOR. For the compounds reported here, the electrophilic Michael acceptor atom of the $\mathrm{C} 2$ substituent was never closer than $\sim 7 \AA$ from the $S^{\gamma}$ atom of $\mathrm{C} 315$ in any of the solutions (taking into account $\mathrm{C} 315$ side chain rotameric flexibility). As discussed in Section 2.1.2 above, there may be multiple reasons for this, providing a rationale for why these compounds do not form covalently-bound adducts with KOR.

The putative binding mode for the most affine analog from the conjugated/nonconjugated series (4d) is shown in Figure $3 b$ and is analogous to the putative binding mode for salvinorin A (1), except that the olefinic side chain of the $\mathrm{C} 2$ substituent is able to effectively fill the small hydrophobic subpocket formed by D138 $8^{3.32}, \mathrm{Y}_{13} 9^{3.33}$ and M142 $2^{3.36}$ (Figure S2). The model shows how the presence of an intervening methyl group between the ester and olefin functionalities, as in $\mathbf{4 d}$, allows the olefinic portion to be directed into the small subpocket. Other analogs in the conjugated and non-conjugated series were not predicted to bind completely into the subpocket, presumably due to steric incompatibilities with methyl groups in the $\mathrm{R}_{2}$ and $\mathrm{R}_{3}$ positions (See Scheme 1) of the $\mathrm{C} 2$ substituent. Interestingly, methyl substitution at the $\mathrm{R}_{1}$ position is tolerated (see $\mathbf{4 b}$ and $\mathbf{4 h}$ ) and the model shows that there is a region of steric tolerance at this locus.

The added steric bulk associated with compounds of the aromatic series $\mathbf{5 a}-\mathbf{n}$ placed the C2 substituent beyond the $\mathrm{Y} 139^{3.33} / \mathrm{M} 142^{3.36}$ subpocket into a hydrophobic pocket bounded by side chains from TM helices 3, 5, and 6 including M142 ${ }^{3.36}, \mathrm{~K} 227^{5.39}$, V230 3.42 and I294 ${ }^{6.55}$. The putative binding mode for the cinnamoyl analog $\mathbf{5 a}$, the most potent and efficacious of the tested compounds in the aromatic series at KOR, is shown in Figure 3c. For 5a, the olefin portion serves as a hydrophobic linker, allowing the phenyl group to effectively engage the hydrophobic regions of its putative binding site. 
The addition of small substituents to the phenyl ring (either electron donating or withdrawing) resulted in significantly decreased affinity for KOR, and the model suggests that this is due to steric intolerance within the binding site. Phenyl substitution at the ortho position is the most well tolerated, and the models show that there is a region of steric tolerance at that position where a substituent may be placed. For analogs with meta and para substitutions, no docked solutions were found that placed the aromatic portion directly into the aforementioned site. The trisubstituted analog $\mathbf{5}$ f has no significant affinity for any of the three opioid receptors, probably due one again to steric intolerance within the orthosteric binding site.

The remarkable observation that the 3-pyridyl analog $\mathbf{5 m}$ has no affinity for the KOR suggests that the polarity introduced by the heterocyclic nitrogen atom cannot be tolerated in the KOR binding site occupied by $\mathbf{5 a}$. The putative binding site for the phenyl group in Figure $3 \mathrm{c}$ is indeed very hydrophobic. On the other hand, $\mathbf{5 m}$ has substantial MOR affinity $\left(K_{\mathrm{i}}=334 \mathrm{nM}\right)$. A comparison of the residues in the putative aromatic binding pocket of KOR and MOR reveals that one of the amino acids is different (KOR, I294 ${ }^{6.55}$; MOR, V302 ${ }^{6.55}$ ). However, this conservative change does not explain the KOR/MOR selectivity of $\mathbf{5 m}$. Thus, an alternate binding mode was proposed for $\mathbf{5 m}$ in MOR; this model is shown in Figure 3d. Here, the pyridine nitrogen of $\mathbf{5 m}$ hydrogen bonds with the non-conserved $\mathrm{N} 127^{2.63}$ (position 2.63: $\mathrm{KOR}=\mathrm{V} ; \mathrm{MOR}=\mathrm{N} ; \mathrm{DOR}=\mathrm{K}$ ) and the furan substituent is sandwiched via $\pi$-stacking interactions between Y326 $6^{7.43}$ and W293 $3^{6.48}$ (mMOR numbering). The isosteric 3-furanyl analog $\mathbf{5 n}$ has excellent MOR affinity $\left(K_{\mathrm{i}}=18 \mathrm{nM}\right)$ and may interact in the same way, although in this case the interaction may be of a more hydrophobic/aromatic nature, as thiophene is a poorer hydrogen bond acceptor that pyridine. The greater hydrophobicity of thiophene compared to pyridine may also explain the greater affinity of $\mathbf{5 n}$ for the KOR $\left(K_{\mathrm{i}}=304 \mathrm{nM}\right)$, and as such may also adopt a binding mode analogous to that proposed for $\mathbf{5 a}$ in Figure 3c.

\section{Conclusion}

A series of potential Michael acceptor-type analogues of salvinorin A were synthesized in an effort to explore the effects of $\mathrm{C}-2$ substitution at opioid receptors. Binding assay results showed that none of the synthesized analogues were able to irreversibly bind to the K-opioid receptor. Aliphatic conjugated and non-conjugated series of analogues showed high binding affinity to the $\kappa$-opioid receptor. Introduction of a cinnamoyl and thiophenylacryloyl group at C-2 had significant impact on affinity, resulting in discovery of new ligands with dual affinity to $\kappa$ - and $\mu$-opioid receptors. Molecular modeling techniques were employed to determine potential binding modes for the compounds. According to molecular modeling data, the electrophilic center of the studied compounds was distant from the $S^{\gamma}$ atom of C315, with a distance of $7 \AA$ or more, confirming the lack of close proximity necessary for covalent binding. 


\section{Materials and methods}

\subsection{Experimental section}

All commercially available reagents were used without further purification unless otherwise noted. The reactions were performed under an argon atmosphere in anhydrous dichloromethane (DCM) purchased from Sigma-Aldrich. The ${ }^{1} \mathrm{H}$ NMR spectra were recorded on a Bruker Avance- 400 spectrometer using $\mathrm{CDCl}_{3}$ as solvent, $\delta$ values are in ppm and coupling constants in Hz. Melting points were determined on an MEL-TEMP ${ }^{\circledR} 3.0$ apparatus and are uncorrected. Thin-layer chromatography (TLC) was performed on $250 \mu \mathrm{m}$ layer (Whatman PE SIL G/UV silica gel) polyester plates using $n$-hexane/EtOAc (1:1) as solvent. TLC spots were visualized with anisaldehyde $/ \mathrm{H}_{2} \mathrm{SO}_{4}$ in methanol. Column chromatography was performed on silica gel $(230 \times 400$ mesh) purchased from Sorbent Technologies (Atlanta, GA). Analytical HPLC was performed on a Waters 2487 apparatus with dual $\lambda$ absorbance detector system using a Phenomenex Luna- $\mathrm{C}_{18}$ column $(4.6 \times 250$ $\mathrm{mm}, 5 \mu \mathrm{m}$ ) with gradient elution at a flow rate $0.5-1.0 \mathrm{~mL} / \mathrm{min}$. Isolation of salvinorin $\mathrm{A}$ was performed according to the earlier reported procedure [30].

\subsection{Synthesis and chemistry}

\subsubsection{General Procedure A: The procedure for the synthesis of compounds}

4a-4h-Compound 3 (15 mg, 1 eq) and triethylamine (1.5-3 eq) were dissolved in DCM (3 $\mathrm{mL}$ ). An appropriate acryloyl chloride (1.5-3 eq) was added, and the reaction mixture was stirred for $3 \mathrm{~h}$. After TLC indicated completion of the reaction, the mixture was quenched with water and the organic layer separated. The organic phase was washed with dilute aqueous $\mathrm{HCl}(0.01 \mathrm{~mol} / \mathrm{L}, 2 \mathrm{~mL})$ followed by saturated $\mathrm{NaHCO}_{3}(2 \mathrm{~mL})$. The organic layer was dried over anhydrous $\mathrm{Na}_{2} \mathrm{SO}_{4}$, evaporated, and the residue was purified by column chromatography ( $\mathrm{SiO}_{2}$; eluent: $n$-hexane/EtOAc) to obtain the target product.

\subsubsection{Genera8/11/2014l Procedure B: The procedure for the synthesis of} compounds 5a-5n-To a solution of compound $\mathbf{3}$ (15 mg, 1 eq) in DCM (3 mL), a catalytic amount of 4-(dimethylamino)pyridine (DMAP) and 1,4-dicyclohexylcarbodimide (DCC) (3 eq), and an appropriate cinnamic or heterocyclic acrylic acid (3 eq) were added. The mixture was stirred at room temperature for $2-5 \mathrm{~h}$. After TLC indicated completion of the reaction, the mixture was concentrated under reduced pressure and the residue was purified by column chromatography $\left(\mathrm{SiO}_{2}\right.$; eluent: $n$-hexane/EtOAc) to yield the target product.

2-O-Acryloylsalvinorin B (4a): Compound 4a was synthesized from $\mathbf{3}$ and acryloyl chloride (procedure A) to afford $13 \mathrm{mg}(73 \%)$ of $\mathbf{4 a}$ as a white solid, mp $169-171{ }^{\circ} \mathrm{C} ;{ }^{1} \mathrm{H}$ NMR (400 MHz, CDCl $\left.)_{3}\right): \delta 7.41(\mathrm{~s}, 1 \mathrm{H}), 7.39$ (s, 1H), 6.49 (d, $\left.J=16.4 \mathrm{~Hz}, 1 \mathrm{H}\right), 6.38$ (s, $1 \mathrm{H}), 6.20(\mathrm{dd}, J=8.0,16.4 \mathrm{~Hz}, 1 \mathrm{H}), 5.93(\mathrm{~d}, J=8.0 \mathrm{~Hz}, 1 \mathrm{H}), 5.52(\mathrm{dd}, J=5.2,11.4 \mathrm{~Hz}$, $1 \mathrm{H}), 5.23(\mathrm{dd}, J=7.6,12.6 \mathrm{~Hz}, 1 \mathrm{H}), 3.73(\mathrm{~s}, 3 \mathrm{H}), 2.78(\mathrm{dd}, J=8.6,8.6 \mathrm{~Hz}, 1 \mathrm{H}), 2.54(\mathrm{dd}, J$ $=5.2,13.4 \mathrm{~Hz}, 1 \mathrm{H}), 2.37-2.33(\mathrm{~m}, 2 \mathrm{H}), 2.22(\mathrm{~s}, 1 \mathrm{H}), 2.19-2.10(\mathrm{~m}, 2 \mathrm{H}), 1.80(\mathrm{ddd}, J=3.0$, 3.0, $10.4 \mathrm{~Hz}, 1 \mathrm{H}), 1.68-1.56(\mathrm{~m}, 3 \mathrm{H}), 1.45$ (s, 3H), 1.15 (s, 3H). ${ }^{13} \mathrm{C}$ NMR (100 MHz, $\left.\mathrm{CDCl}_{3}\right): \delta 201.84,171.75,171.21,164.71,143.57,139.30,132.29,127.36,125.21,108.40$, 75.21, 72.01, 63.91, 53.67, 51.91, 51.37, 43.33, 42.06, 38.08, 35.06, 30.75, 17.93, 16.17, 
15.18. HRESIMS (m/z): $[\mathrm{M}+\mathrm{H}]^{+}$calculated for $\mathrm{C}_{24} \mathrm{H}_{29} \mathrm{O}_{8}, 445.1784$; found, 445.1761. HPLC $t_{\mathrm{R}}=10.974 \mathrm{~min}$; purity $=98.69 \%$.

2-O-Methacryloylsalvinorin B (4b): Compound $\mathbf{4 b}$ was synthesized from 3 and methacryloyl chloride (procedure A) to obtain $16 \mathrm{mg}$ (70\%) of $\mathbf{4 b}$ as a white solid, mp 196$198{ }^{\circ} \mathbf{C}$. The ${ }^{1} \mathrm{H}$ NMR spectrum of $\mathbf{4 b}$ was consistent with that previously reported.[21] ${ }^{13} \mathrm{C}$ NMR (100 MHz, $\left.\mathrm{CDCl}_{3}\right): \delta 201.97,171.67,171.24,166.15,143.61,139.47,135.30$, $126.88,125.12,108.45,75.23,72.03,63.95,53.50,51.96,51.34,43.19,42.08,38.10,35.43$, 30.84, 18.19, 16.36, 15.16. HRESIMS (m/z): $[\mathrm{M}+\mathrm{H}]^{+}$calculated for $\mathrm{C}_{25} \mathrm{H}_{31} \mathrm{O}_{8}, 459.1941$; found, 459.1935. HPLC $t_{\mathrm{R}}=19.306 \mathrm{~min}$; purity $=99.01 \%$.

2-O-( $\mathbf{3}^{\prime}, \mathbf{3}^{\prime}$-Dimethylacryloyl)salvinorin B (4c): Compound $4 \mathbf{c}$ was synthesized from 3 and 3,3-dimethylacryloyl chloride (procedure A) to afford $9 \mathrm{mg}(51 \%)$ of $\mathbf{4 c}$ as a white solid, mp $183-185{ }^{\circ} \mathrm{C} ;{ }^{1} \mathrm{H}$ NMR $\left(400 \mathrm{MHz}, \mathrm{CDCl}_{3}\right): \delta 7.41(\mathrm{~s}, 1 \mathrm{H}), 7.38(\mathrm{~s}, 1 \mathrm{H}), 6.38(\mathrm{~s}, 1 \mathrm{H})$, $5.79(\mathrm{~s}, 1 \mathrm{H}), 5.51(\mathrm{dd}, J=5.2,11.5 \mathrm{~Hz}, 1 \mathrm{H}), 5.20(\mathrm{dd}, J=7.6,12.6 \mathrm{~Hz}, 1 \mathrm{H}), 3.71(\mathrm{~s}, 3 \mathrm{H})$, $2.78(\mathrm{dd}, J=8.6,8.6 \mathrm{~Hz}, 1 \mathrm{H}), 2.51(\mathrm{dd}, J=5.2,13.4 \mathrm{~Hz}, 1 \mathrm{H}), 2.32-2.28(\mathrm{~m}, 2 \mathrm{H}), 2.20$ (s, $1 \mathrm{H}), 2.16(\mathrm{~s}, 3 \mathrm{H}), 2.13-2.07(\mathrm{~m}, 2 \mathrm{H}), 1.92(\mathrm{~s}, 3 \mathrm{H}), 1.80$ (ddd, $J=3.0,3.0,10.4 \mathrm{~Hz}, 1 \mathrm{H})$, $1.67-1.55(\mathrm{~m}, 3 \mathrm{H}), 1.44(\mathrm{~s}, 3 \mathrm{H}), 1.14(\mathrm{~s}, 3 \mathrm{H}) .{ }^{13} \mathrm{C} \mathrm{NMR}\left(100 \mathrm{MHz}, \mathrm{CDCl}_{3}\right): \delta 202.33$, 171.68, 171.23, 164.99, 159.16, 143.64, 139.49, 125.13, 114.85, 108.38, 73.96, 71.60, 63.87, 53.34, 51.58, 51.30, 43.07, 41.76, 37.90, 35.33, 30.93, 27.35, 20.46, 18.13, 16.29, 14.99. HRESIMS (m/z): $[\mathrm{M}+\mathrm{H}]^{+}$calculated for $\mathrm{C}_{26} \mathrm{H}_{33} \mathrm{O}_{8}, 473.2097$; found, 473.2063 . HPLC $t_{\mathrm{R}}=21.211 \mathrm{~min}$; purity $=98.91 \%$.

2-O-(3'-Methylbut-3'-enoyl)salvinorin B (4d): Compound $\mathbf{4 d}(8.5 \mathrm{mg}, 49 \%)$ was obtained as a by-product from the reaction of $\mathbf{3}$ and 3,3-dimethylacryloyl chloride (procedure $\mathrm{A}$ ) as a white solid, mp $168-170{ }^{\circ} \mathrm{C} ;{ }^{1} \mathrm{H}$ NMR $\left(400 \mathrm{MHz}, \mathrm{CDCl}_{3}\right): \delta 7.41(\mathrm{~s}, 1 \mathrm{H}), 7.39(\mathrm{~s}, 1 \mathrm{H}), 6.38$ (s, 1H), $5.51(\mathrm{dd}, J=5.2,11.6 \mathrm{~Hz}, 1 \mathrm{H}), 5.16(\mathrm{dd}, J=7.6,12.6 \mathrm{~Hz}, 1 \mathrm{H}), 4.94(\mathrm{~s}, 1 \mathrm{H}), 4.90(\mathrm{~s}$, $1 \mathrm{H}), 3.71(\mathrm{~s}, 3 \mathrm{H}), 3.15(\mathrm{~s}, 2 \mathrm{H}), 2.76(\mathrm{dd}, J=8.6,8.6 \mathrm{~Hz}, 1 \mathrm{H}), 2.52(\mathrm{dd}, J=5.2,13.4 \mathrm{~Hz}$, $1 \mathrm{H}), 2.30-2.28(\mathrm{~m}, 2 \mathrm{H}), 2.21(\mathrm{~s}, 1 \mathrm{H}), 2.16-2.07(\mathrm{~m}, 2 \mathrm{H}), 1.85(\mathrm{~s}, 3 \mathrm{H}), 1.82$ (ddd, $J=3.0$, 3.0, $10.4 \mathrm{~Hz}, 1 \mathrm{H}), 1.68-1.56(\mathrm{~m}, 3 \mathrm{H}), 1.44$ (s, 3H), 1.14 (s, 3H). ${ }^{13} \mathrm{C}$ NMR $(100 \mathrm{MHz}$, $\left.\mathrm{CDCl}_{3}\right): \delta 201.70,171.52,171.07,170.38,143.75,139.53,137.99,125.21,115.17,108.49$, 75.13, 71.80, 63.79, 53.50, 51.94, 51.32, 43.20, 42.90, 42.07, 38.17, 35.43, 30.73, 22.46, 18.16, 16.40, 15.10. HRESIMS (m/z): $[\mathrm{M}+\mathrm{Na}]^{+}$calculated for $\mathrm{C}_{26} \mathrm{H}_{32} \mathrm{O}_{8} \mathrm{Na}, 495.1996$; found, 495.1959. HPLC $t_{\mathrm{R}}=11.457 \mathrm{~min}$; purity $=97.54 \%$.

2-O-Crotonoylsalvinorin B (4e): Compound $4 \mathrm{e}$ was synthesized from 3 and crotonyl chloride (procedure A) to obtain $8 \mathrm{mg}(49 \%)$ of $4 \mathbf{e}$ as a white solid, mp $163-165{ }^{\circ} \mathrm{C} ;{ }^{1} \mathrm{H}$ NMR (400 MHz, $\left.\mathrm{CDCl}_{3}\right): \delta 7.41(\mathrm{~s}, 1 \mathrm{H}), 7.39(\mathrm{~s}, 1 \mathrm{H}), 7.13-7.04(\mathrm{~m}, 1 \mathrm{H}), 6.38(\mathrm{~s}, 1 \mathrm{H}), 5.93$ (d, $J=7.8 \mathrm{~Hz}, 1 \mathrm{H}), 5.51(\mathrm{dd}, J=5.2,11.5 \mathrm{~Hz}, 1 \mathrm{H}), 5.22(\mathrm{dd}, J=7.6,12.6 \mathrm{~Hz}, 1 \mathrm{H}), 3.73$ (s, $3 \mathrm{H}), 2.79(\mathrm{dd}, J=8.6,8.6 \mathrm{~Hz}, 1 \mathrm{H}), 2.51(\mathrm{dd}, J=5.2,13.4 \mathrm{~Hz}, 1 \mathrm{H}), 2.35-2.28(\mathrm{~m}, 2 \mathrm{H}), 2.25$ (s, 1H), 2.13-2.07 (m, 2H), $1.91(\mathrm{~d}, J=7.0 \mathrm{~Hz}, 3 \mathrm{H}), 1.80$ (ddd, $J=3.0,3.0,10.4 \mathrm{~Hz}, 1 \mathrm{H})$, $1.65-1.55$ (m, 3H), 1.45 (s, 3H), $1.12(\mathrm{~s}, 3 \mathrm{H}) .{ }^{13} \mathrm{C}$ NMR (100 MHz, $\left.\mathrm{CDCl}_{3}\right): \delta 202.13$, 171.62, 171.23, 165.00, 146.67, 143.64, 139.48, 125.22, 121.54, 108.45, 74.79, 72.00, 63.84, 53.43, 51.91, 51.27, 43.19, 42.06, 38.09, 35.41, 30.84, 18.11, 16.39, 15.14. 
HRESIMS (m/z): $[\mathrm{M}+\mathrm{H}]^{+}$calculated for $\mathrm{C}_{25} \mathrm{H}_{31} \mathrm{O}_{8}, 459.1941$; found, 459.1928. HPLC $t_{\mathrm{R}}=$ $15.681 \mathrm{~min}$; purity $=98.81 \%$.

2-O-(3'-Butenoyl)salvinorin B (4f): Compound $\mathbf{4 f}(9 \mathrm{mg}, 51 \%)$ was obtained as by-product from the reaction of $\mathbf{3}$ and crotonyl chloride (procedure A) as a white solid, mp 157-159 ${ }^{\circ} \mathrm{C} ;{ }^{1} \mathrm{H}$ NMR (400 MHz, $\left.\mathrm{CDCl}_{3}\right): \delta 7.43(\mathrm{~s}, 1 \mathrm{H}), 7.40(\mathrm{~s}, 1 \mathrm{H}), 6.50-6.44(\mathrm{~m}, 1 \mathrm{H}), 6.39(\mathrm{~s}$, $1 \mathrm{H}), 5.92(\mathrm{~s}, 1 \mathrm{H}), 5.90(\mathrm{~s}, 1 \mathrm{H}), 5.54(\mathrm{dd}, J=5.2,11.5 \mathrm{~Hz}, 1 \mathrm{H}), 5.22(\mathrm{dd}, J=7.6,12.6 \mathrm{~Hz}$, $1 \mathrm{H}), 3.74(\mathrm{~s}, 3 \mathrm{H}), 3.40-3.31(\mathrm{~m}, 2 \mathrm{H}), 2.78(\mathrm{dd}, J=8.6,8.6 \mathrm{~Hz}, 1 \mathrm{H}), 2.53(\mathrm{dd}, J=5.2,13.4$ $\mathrm{Hz}, 1 \mathrm{H}), 2.36-2.29$ (m, 2H), 2.21 (s, 1H), 2.17-1.97 (m, 2H), 1.81 (ddd, $J=3.0,3.0,10.4$ $\mathrm{Hz}, 1 \mathrm{H}), 1.65-1.56(\mathrm{~m}, 3 \mathrm{H}), 1.47$ (s, 3H), 1.14 (s, 3H). $\left.{ }^{13} \mathrm{C} \mathrm{NMR} \mathrm{(100} \mathrm{MHz,} \mathrm{CDCl}_{3}\right): \delta$ $202.43,171.65,171.54,170.36,143.69,139.48,137.96,125.23,115.23,108.42,75.13$, 72.00, 64.03, 53.66, 51.95, 51.36, 43.41, 42.88, 42.12, 38.33, 35.45, 30.94, 18.14, 16.40, 15.16. HRESIMS (m/z): $[\mathrm{M}+\mathrm{Na}]^{+}$calculated for $\mathrm{C}_{25} \mathrm{H}_{30} \mathrm{O}_{8} \mathrm{Na}$, 481.1839; found, 481.1804 . HPLC $t_{\mathrm{R}}=23.537 \mathrm{~min}$; purity $=98.88 \%$.

2-O-( $\mathbf{2}^{\prime}, \mathbf{3}^{\prime}$-Dimethylacryloyl)salvinorin B (4g): Compound $\mathbf{4 g}$ was synthesized from $\mathbf{3}$ and 2,3-dimethylacryloyl chloride (procedure A) to afford $8.8 \mathrm{mg}(49 \%)$ of $\mathbf{4 g}$ as a white solid, mp 161-163 ${ }^{\circ} \mathrm{C} ;{ }^{1} \mathrm{H}$ NMR $\left(400 \mathrm{MHz}, \mathrm{CDCl}_{3}\right): \delta 7.41(\mathrm{~s}, 1 \mathrm{H}), 7.40(\mathrm{~s}, 1 \mathrm{H}), 7.14-7.05(\mathrm{~m}$, $2 \mathrm{H}), 6.38(\mathrm{~s}, 1 \mathrm{H}), 5.52(\mathrm{dd}, J=5.2,11.5 \mathrm{~Hz}, 1 \mathrm{H}), 5.22(\mathrm{dd}, J=7.6,12.6 \mathrm{~Hz}, 1 \mathrm{H}), 3.74(\mathrm{~s}$, $3 \mathrm{H}), 2.77(\mathrm{dd}, J=8.6,8.6 \mathrm{~Hz}, 1 \mathrm{H}), 2.55(\mathrm{dd}, J=5.2,13.4 \mathrm{~Hz}, 1 \mathrm{H}), 2.34-2.28(\mathrm{~m}, 2 \mathrm{H}), 2.20$ (s, 1H), 2.16-2.07 (m, 2H), $1.92(\mathrm{~d}, J=5.6 \mathrm{~Hz}, 3 \mathrm{H}), 1.81(\mathrm{ddd}, J=3.0,3.0,10.4 \mathrm{~Hz}, 1 \mathrm{H})$, 1.79 (s, 3H), $1.67-1.56(\mathrm{~m}, 3 \mathrm{H}), 1.46(\mathrm{~s}, 3 \mathrm{H}), 1.14(\mathrm{~s}, 3 \mathrm{H}) .{ }^{13} \mathrm{C} \mathrm{NMR}\left(100 \mathrm{MHz}, \mathrm{CDCl}_{3}\right): \delta$ $202.07,171.78,170.84,165.22,146.69,143.52,139.72,125.02,121.56,108.27,75.28$, 72.25, 63.78, 53.32, 52.26, 51.04, 43.55, 41.82, 35.17, 30.71, 29.52, 27.82, 23.57, 17.86, 16.22, 14.54. HRESIMS (m/z): $[\mathrm{M}+\mathrm{H}]^{+}$calculated for $\mathrm{C}_{26} \mathrm{H}_{33} \mathrm{O}_{8}, 473.2097$; found, 473.2059. HPLC $t_{\mathrm{R}}=17.950 \mathrm{~min}$; purity $=98.08 \%$.

2-O-(2'-Methyl-3'-butenoyl)salvinorin B (4h): Compound $\mathbf{4 h}$ (9.5 mg, 51\%) was obtained as a by-product from the reaction of $\mathbf{3}$ and 2,3-dimethylacryloyl chloride (procedure $\mathrm{A}$ ) as a white solid, mp $168-170{ }^{\circ} \mathrm{C} ;{ }^{1} \mathrm{H}$ NMR $\left(400 \mathrm{MHz}, \mathrm{CDCl}_{3}\right): \delta 7.40(\mathrm{~s}, 1 \mathrm{H}), 7.38(\mathrm{~s}, 1 \mathrm{H}), 6.37$ $(\mathrm{s}, 1 \mathrm{H}), 6.00-5.88(\mathrm{~m}, 1 \mathrm{H}), 5.48(\mathrm{dd}, J=5.2,11.6 \mathrm{~Hz}, 1 \mathrm{H}), 5.23-5.11(\mathrm{~m}, 3 \mathrm{H}), 3.71(\mathrm{~s}, 3 \mathrm{H})$, $3.35-3.25(\mathrm{~m}, 1 \mathrm{H}), 2.76(\mathrm{dd}, J=8.6,8.6 \mathrm{~Hz}, 1 \mathrm{H}), 2.49(\mathrm{dd}, J=5.2,13.4 \mathrm{~Hz}, 1 \mathrm{H}), 2.35-2.26$ (m, 2H), $2.21(\mathrm{~s}, 1 \mathrm{H}), 2.16-2.05(\mathrm{~m}, 2 \mathrm{H}), 1.81(\mathrm{dd}, J=3.0,3.0,10.4 \mathrm{~Hz}, 1 \mathrm{H}), 1.67-1.54(\mathrm{~m}$, $3 \mathrm{H}), 1.43(\mathrm{~s}, 3 \mathrm{H}), 1.34(\mathrm{~d}, J=5.0 \mathrm{~Hz}, 3 \mathrm{H}), 1.11(\mathrm{~s}, 3 \mathrm{H}) .{ }^{13} \mathrm{C} \mathrm{NMR}\left(100 \mathrm{MHz}, \mathrm{CDCl}_{3}\right): \delta$ 201.77, 173.47, 171.56, 171.17, 143.59, 139.53, 136.56, 125.08, 116.37, 108.49, 74.78, 71.96, 63.88, 53.70, 51.93, 51.25, 43.24, 41.98, 38.12, 35.36, 30.69, 18.17, 16.82, 16.41, 15.12. HRESIMS (m/z): $[\mathrm{M}+\mathrm{H}]^{+}$calculated for $\mathrm{C}_{26} \mathrm{H}_{33} \mathrm{O}_{8}, 473.5275$; found, 473.5254 . HPLC $t_{\mathrm{R}}=30.242 \mathrm{~min}$; purity $=98.97 \%$.

2-O-Cinnamoylsalvinorin B (5a): According to general procedure B, the title compound (24 mg, 92\%) was obtained as a white powder from 3 and cinnamic acid. mp 202-204 ${ }^{\circ} \mathrm{C} ;{ }^{1} \mathrm{H}$ NMR (400 MHz, $\left.\mathrm{CDCl}_{3}\right): \delta 7.77(\mathrm{~d}, J=16.0 \mathrm{~Hz}, 1 \mathrm{H}), 7.55-7.53(\mathrm{~m}, 2 \mathrm{H}), 7.42-7.39$ $(\mathrm{m}, 5 \mathrm{H}), 6.52(\mathrm{~d}, J=16.0 \mathrm{~Hz}, 1 \mathrm{H}), 6.38(\mathrm{~s}, 1 \mathrm{H}), 5.53(\mathrm{dd}, J=5.2,11.4 \mathrm{~Hz}, 1 \mathrm{H}), 5.30(\mathrm{dd}, J$ $=7.6,12.6 \mathrm{~Hz}, 1 \mathrm{H}), 3.74(\mathrm{~s}, 3 \mathrm{H}), 2.80(\mathrm{dd}, J=8.6,8.6 \mathrm{~Hz}, 1 \mathrm{H}), 2.56(\mathrm{dd}, J=5.2,13.4 \mathrm{~Hz}$, $1 \mathrm{H}), 2.42-2.37(\mathrm{~m}, 2 \mathrm{H}), 2.23(\mathrm{~s}, 1 \mathrm{H}), 2.20-2.08(\mathrm{~m}, 2 \mathrm{H}), 1.82(\mathrm{ddd}, J=3.0,3.0,10.4 \mathrm{~Hz}$, 
1H), 1.72-1.59 (m, 3H), 1.47 (s, 3H), 1.15 (s, 3H). $\left.{ }^{13} \mathrm{C} \mathrm{NMR} \mathrm{(100} \mathrm{MHz,} \mathrm{CDCl}_{3}\right): \delta 202.23$, $171.53,171.13,165.61,146.46,143.64,139.46,134.11,130.64,129.01,128.18,125.24$, 116.66, 108.45, 75.14, 71.99, 64.00, 53.56, 51.97, 51.41, 43.21, 42.21, 38.18, 35.48, 30.93, 18.16, 16.45, 15.20. HRESIMS (m/z): $[\mathrm{M}+\mathrm{H}]^{+}$calculated for $\mathrm{C}_{30} \mathrm{H}_{33} \mathrm{O}_{8}, 521.2097$; found, 521.2069. HPLC $t_{\mathrm{R}}=29.642 \mathrm{~min}$; purity $=99.14 \%$.

2-O-(2"-Methoxycinnamoyl)salvinorin B (5b): According to general procedure B, the compound $\mathbf{5 b}$ (13 mg, 63\%) was obtained as a white solid from $\mathbf{3}$ and 2-methoxycinnamic acid. mp 153-155 ${ }^{\circ} \mathrm{C} ;{ }^{1} \mathrm{H}$ NMR (400 MHz, $\left.\mathrm{CDCl}_{3}\right): 88.06(\mathrm{~d}, J=16.0 \mathrm{~Hz}, 1 \mathrm{H}), 7.52(\mathrm{~d}, J=$ $8.0 \mathrm{~Hz}, 1 \mathrm{H}), 7.42-7.34(\mathrm{~m}, 3 \mathrm{H}), 6.96-6.91(\mathrm{~m}, 2 \mathrm{H}), 6.63(\mathrm{~d}, J=16.0 \mathrm{~Hz}, 1 \mathrm{H}), 6.39(\mathrm{~s}, 1 \mathrm{H})$, $5.51(\mathrm{dd}, J=5.2,11.4 \mathrm{~Hz}, 1 \mathrm{H}), 5.30(\mathrm{dd}, J=7.6,12.6 \mathrm{~Hz}, 1 \mathrm{H}), 3.88(\mathrm{~s}, 3 \mathrm{H}), 3.73(\mathrm{~s}, 3 \mathrm{H})$, $2.80(\mathrm{dd}, J=8.6,8.6 \mathrm{~Hz}, 1 \mathrm{H}), 2.54(\mathrm{dd}, J=5.2,13.4 \mathrm{~Hz}, 1 \mathrm{H}), 2.41-2.36(\mathrm{~m}, 2 \mathrm{H}), 2.27(\mathrm{~s}$, $1 \mathrm{H}), 2.17-2.09(\mathrm{~m}, 2 \mathrm{H}), 1.82(\mathrm{ddd}, J=3.0,3.0,10.4 \mathrm{~Hz}, 1 \mathrm{H}), 1.68-1.56(\mathrm{~m}, 3 \mathrm{H}), 1.45(\mathrm{~s}$, $3 \mathrm{H}), 1.14(\mathrm{~s}, 3 \mathrm{H}) .{ }^{13} \mathrm{C} \mathrm{NMR}\left(100 \mathrm{MHz}, \mathrm{CDCl}_{3}\right): \delta 202.22,171.70,171.27,166.35,158.45$, $143.69,141.85,139.48,131.90,129.21,125.26,123.01,120.73,117.22,111.20,108.50$, 75.06, 72.08, 63.90, 60.39, 55.41, 53.61, 51.99, 51.34, 43.26, 42.11, 38.19, 35.45, 30.92, 18.14, 16.42, 15.24. HRESIMS (m/z): $[\mathrm{M}+\mathrm{H}]^{+}$calculated for $\mathrm{C}_{31} \mathrm{H}_{35} \mathrm{O}_{9}, 551.2203$; found, 551.2235. HPLC $t_{\mathrm{R}}=32.453 \mathrm{~min}$; purity $=97.98 \%$.

2-O-(4"-Methoxycinnamoyl)salvinorin B (5c): According to general procedure B, the compound $\mathbf{5 c}(15 \mathrm{mg}, 65 \%)$ was yielded as a white solid from $\mathbf{3}$ and 4-methoxycinnamic acid. mp 191-193 ${ }^{\circ} \mathrm{C} ;{ }^{1} \mathrm{H}$ NMR (400 MHz, $\left.\mathrm{CDCl}_{3}\right): \delta 7.72(\mathrm{~d}, J=16.0 \mathrm{~Hz}, 1 \mathrm{H}), 7.49(\mathrm{~d}, J=$ $8.0 \mathrm{~Hz}, 1 \mathrm{H}), 7.42(\mathrm{~s}, 1 \mathrm{H}), 7.40(\mathrm{~s}, 1 \mathrm{H}), 6.91(\mathrm{~d}, J=8.0 \mathrm{~Hz}, 2 \mathrm{H}), 6.41(\mathrm{~d}, J=16.0 \mathrm{~Hz}, 1 \mathrm{H})$, $6.37(\mathrm{~s}, 1 \mathrm{H}), 5.52(\mathrm{dd}, J=5.2,11.4 \mathrm{~Hz}, 1 \mathrm{H}), 5.30(\mathrm{dd}, J=7.6,12.6 \mathrm{~Hz}, 1 \mathrm{H}), 3.85(\mathrm{~s}, 3 \mathrm{H})$, $3.74(\mathrm{~s}, 3 \mathrm{H}), 2.81(\mathrm{dd}, J=8.6,8.6 \mathrm{~Hz}, 1 \mathrm{H}), 2.54(\mathrm{~d}, J=5.2,13.4 \mathrm{~Hz}, 1 \mathrm{H}), 2.41-2.37(\mathrm{~m}$, $2 \mathrm{H}), 2.24(\mathrm{~s}, 1 \mathrm{H}), 2.19-2.08(\mathrm{~m}, 2 \mathrm{H}), 1.83(\mathrm{ddd}, J=3.0,3.0,10.4 \mathrm{~Hz}, 1 \mathrm{H}), 1.72-1.58(\mathrm{~m}$, $3 \mathrm{H}), 1.47$ (s, 3H), 1.16 (s, 3H). ${ }^{13} \mathrm{C}$ NMR (100 MHz, $\mathrm{CDCl}_{3}$ ): $\delta 202.25,171.68,171.24$, 166.10, 161.63, 146.17, 143.69, 139.41, 129.89, 126.93, 125.13, 114.38, 114.06, 108.47, 74.92, 72.08, 64.10, 55.38, 53.65, 51.96, 51.42, 43.40, 42.10, 38.19, 35.49, 30.94, 18.19, 16.44, 15.23. HRESIMS (m/z): $[\mathrm{M}+\mathrm{Na}]^{+}$calculated for $\mathrm{C}_{31} \mathrm{H}_{35} \mathrm{O}_{9} \mathrm{Na}, 573.2203$; found, 573.2169 . HPLC $t_{\mathrm{R}}=30.539 \mathrm{~min}$; purity $=96.13 \%$.

2-O-(2",5"-Dimethoxycinnamoyl)salvinorin B (5d): According to general procedure B, the title compound $\mathbf{5 d}(13 \mathrm{mg}, 60 \%)$ was afforded as a white solid from $\mathbf{3}$ and 2,5dimethoxycinnamic acid. $\mathrm{mp} 217-219^{\circ} \mathrm{C} ;{ }^{1} \mathrm{H}$ NMR $\left(400 \mathrm{MHz}, \mathrm{CDCl}_{3}\right): \delta 8.05(\mathrm{~d}, J=16.4$ $\mathrm{Hz}, 1 \mathrm{H}), 7.43(\mathrm{~s}, 1 \mathrm{H}), 7.40(\mathrm{~s}, 1 \mathrm{H}), 7.06(\mathrm{~s}, 1 \mathrm{H}), 6.95(\mathrm{~d}, J=8.0 \mathrm{~Hz}, 1 \mathrm{H}), 6.92(\mathrm{~d}, J=8.0$ $\mathrm{Hz}, 1 \mathrm{H}), 6.60(\mathrm{~d}, J=16.4 \mathrm{~Hz}, 1 \mathrm{H}), 6.40(\mathrm{~s}, 1 \mathrm{H}), 5.54(\mathrm{dd}, J=5.2,11.4 \mathrm{~Hz}, 1 \mathrm{H}), 5.32(\mathrm{dd}, J$ $=7.6,12.6 \mathrm{~Hz}, 1 \mathrm{H}), 3.85(\mathrm{~s}, 3 \mathrm{H}), 3.80(\mathrm{~s}, 3 \mathrm{H}), 3.75(\mathrm{~s}, 3 \mathrm{H}), 2.82(\mathrm{dd}, J=8.6,8.6 \mathrm{~Hz}, 1 \mathrm{H})$, $2.54(\mathrm{dd}, J=5.2,13.4 \mathrm{~Hz}, 1 \mathrm{H}), 2.43-2.37(\mathrm{~m}, 2 \mathrm{H}), 2.24(\mathrm{~s}, 1 \mathrm{H}), 2.19-2.08(\mathrm{~m}, 2 \mathrm{H}), 1.80$ (ddd, $J=3.0,3.0,10.4 \mathrm{~Hz}, 1 \mathrm{H}), 1.71-1.58(\mathrm{~m}, 3 \mathrm{H}), 1.48(\mathrm{~s}, 3 \mathrm{H}), 1.16(\mathrm{~s}, 3 \mathrm{H}) .{ }^{13} \mathrm{C}$ NMR $\left(100 \mathrm{MHz}, \mathrm{CDCl}_{3}\right): \delta 202.17,171.62,171.18,166.18,153.45,153.02,143.68,141.64$, $139.43,125.22,123.58,117.67,117.26,113.32,112.44,108.40,75.00,72.08,64.11,56.03$, 55.78, 53.67, 51.96, 51.41, 42.26, 38.21, 35.53, 33.94, 30.97, 18.20, 16.45, 15.21.

HRESIMS (m/z): $[\mathrm{M}+\mathrm{H}]^{+}$calculated for $\mathrm{C}_{32} \mathrm{H}_{37} \mathrm{O}_{10}, 581.2308$; found, 581.2287. HPLC $t_{\mathrm{R}}$ $=29.079 \mathrm{~min}$; purity $=98.12 \%$. 
2-O-(2", $\mathbf{4}^{\prime \prime}$-Dimethoxycinnamoyl)salvinorin B (5e): According to general procedure B, the compound $\mathbf{5 e}(14 \mathrm{mg}, 61 \%)$ was obtained as a white solid from $\mathbf{3}$ and 2,4-

dimethoxycinnamic acid. mp $178-180{ }^{\circ} \mathrm{C} ;{ }^{1} \mathrm{H}$ NMR $\left(400 \mathrm{MHz}, \mathrm{CDCl}_{3}\right): \delta 7.98$ (d, $J=16.0$ $\mathrm{Hz}, 1 \mathrm{H}), 7.46-7.40(\mathrm{~m}, 3 \mathrm{H}), 6.55-6.44(\mathrm{~m}, 3 \mathrm{H}), 6.39(\mathrm{~s}, 1 \mathrm{H}), 5.52(\mathrm{dd}, J=5.2,11.4 \mathrm{~Hz}$, $1 \mathrm{H}), 5.31(\mathrm{dd}, J=7.6,12.6 \mathrm{~Hz}, 1 \mathrm{H}), 3.87(\mathrm{~s}, 3 \mathrm{H}), 3.84(\mathrm{~s}, 3 \mathrm{H}), 3.74$ (s, 3H), 2.81 (dd, $J=$ 8.6, $8.6 \mathrm{~Hz}, 1 \mathrm{H}), 2.54(\mathrm{dd}, J=5.2,13.4 \mathrm{~Hz}, 1 \mathrm{H}), 2.41-2.36(\mathrm{~m}, 2 \mathrm{H}), 2.24(\mathrm{~s}, 1 \mathrm{H}), 2.19-2.08$ (m, 2H), 1.83 (ddd, $J=3.0,3.0,10.4 \mathrm{~Hz}, 1 \mathrm{H}), 1.71-1.58(\mathrm{~m}, 3 \mathrm{H}), 1.46(\mathrm{~s}, 3 \mathrm{H}), 1.15$ (s, $3 \mathrm{H}) .{ }^{13} \mathrm{C} \mathrm{NMR}\left(100 \mathrm{MHz}, \mathrm{CDCl}_{3}\right): \delta 202.51,171.80,171.32,166.67,163.04,159.96$, 143.73, 141.65, 139.36, 130.96, 125.13, 116.41, 114.36, 108.38, 105.32, 99.39, 74.83, 72.08, 64.07, 55.56, 53.76, 51.91, 51.39, 43.31, 42.02, 38.19, 35.51, 30.94, 18.19, 16.43, 15.16. HRESIMS (m/z): $[\mathrm{M}+\mathrm{H}]^{+}$calculated for $\mathrm{C}_{32} \mathrm{H}_{36} \mathrm{O}_{10} \mathrm{Na}, 603.2342$; found, 603.2389 . HPLC $t_{\mathrm{R}}=23.628 \mathrm{~min}$; purity $=98.69 \%$.

2-O-(3", $4^{\prime \prime}, 5^{\prime \prime}-$ Trimethoxycinnamoyl)salvinorin B (5f): According to the general procedure B, the compound $\mathbf{5 f}(16 \mathrm{mg}, 64 \%)$ was yielded as a white solid from $\mathbf{3}$ and 3, 4,5trimethoxycinnamic acid. $\mathrm{mp} 222-224{ }^{\circ} \mathrm{C} ;{ }^{1} \mathrm{H}$ NMR $\left(400 \mathrm{MHz}, \mathrm{CDCl}_{3}\right): \delta 7.68$ (d, $J=16.0$ $\mathrm{Hz}, 1 \mathrm{H}), 7.42$ (s, 1H), 7.39 (s, 1H), 6.77 (s, 2H), 6.43 (d, $J=16.0 \mathrm{~Hz}, 1 \mathrm{H}), 6.39$ (s, 1H), 5.53 (dd, $J=5.2,11.4 \mathrm{~Hz}, 1 \mathrm{H}), 5.30(\mathrm{dd}, J=7.6,12.6 \mathrm{~Hz}, 1 \mathrm{H}), 3.88(\mathrm{~s}, 9 \mathrm{H}), 3.73(\mathrm{~s}, 3 \mathrm{H}), 2.81$ $(\mathrm{dd}, J=8.6,8.6 \mathrm{~Hz}, 1 \mathrm{H}), 2.52(\mathrm{dd}, J=5.2,13.4 \mathrm{~Hz}, 1 \mathrm{H}), 2.41-2.37(\mathrm{~m}, 2 \mathrm{H}), 2.24(\mathrm{~s}, 1 \mathrm{H})$, 2.18-2.09 (m, 2H), 1.82 (ddd, $J=3.0,3.0,10.4 \mathrm{~Hz}, 1 \mathrm{H}), 1.73-1.58(\mathrm{~m}, 3 \mathrm{H}), 1.46(\mathrm{~s}, 3 \mathrm{H})$, 1.15 (s, 3H). ${ }^{13} \mathrm{C}$ NMR $\left(100 \mathrm{MHz}, \mathrm{CDCl}_{3}\right): \delta 202.22,171.61,171.07,165.66,153.38$, 146.32, 143.71, 140.31, 139.29, 129.61, 125.26, 115.93, 108.40, 105.45, 75.07, 72.04, 60.88, 56.16, 53.55, 51.99, 51.34, 43.31, 42.11, 38.19, 35.51, 30.89, 18.18, 16.41, 15.22. HRESIMS (m/z): $[\mathrm{M}+\mathrm{H}]^{+}$calculated for $\mathrm{C}_{33} \mathrm{H}_{39} \mathrm{O}_{11}, 611.2414$; found, 611.2403. HPLC $t_{\mathrm{R}}$ $=28.904 \mathrm{~min}$; purity $=99.08 \%$.

2-O-(3",4"-Dioxymethylenecinnamoyl)salvinorin B (5g): According to the general procedure $\mathrm{B}$, the title compound ( $13 \mathrm{mg}, 61 \%$ ) was yielded as a white solid from $\mathbf{3}$ and 3,4dioxymethylenecinnamic acid. mp $177-179{ }^{\circ} \mathrm{C} ;{ }^{1} \mathrm{H}$ NMR (400 MHz, $\left.\mathrm{CDCl}_{3}\right): \delta 7.67$ (d, $J=$ $16.0 \mathrm{~Hz}, 1 \mathrm{H}), 7.42(\mathrm{~s}, 1 \mathrm{H}), 7.39(\mathrm{~s}, 1 \mathrm{H}), 7.08-7.01(\mathrm{~m}, 2 \mathrm{H}), 6.82(\mathrm{~d}, J=8.0 \mathrm{~Hz}, 2 \mathrm{H}), 6.39$ $(\mathrm{s}, 1 \mathrm{H}), 6.34(\mathrm{~d}, J=16.0 \mathrm{~Hz}, 1 \mathrm{H}), 6.02(\mathrm{~s}, 2 \mathrm{H}), 5.53(\mathrm{dd}, J=5.2,11.4 \mathrm{~Hz}, 1 \mathrm{H}), 5.29(\mathrm{dd}, J=$ 7.6, $12.6 \mathrm{~Hz}, 1 \mathrm{H}), 3.74(\mathrm{~s}, 3 \mathrm{H}), 2.82(\mathrm{dd}, J=8.6,8.6 \mathrm{~Hz}, 1 \mathrm{H}), 2.53(\mathrm{dd}, J=5.2,13.4 \mathrm{~Hz}$, $1 \mathrm{H}), 2.41-2.37(\mathrm{~m}, 2 \mathrm{H}), 2.24(\mathrm{~s}, 1 \mathrm{H}), 2.20-2.08(\mathrm{~m}, 2 \mathrm{H}), 1.83$ (ddd, $J=3.0,3.0,10.4 \mathrm{~Hz}$, $1 \mathrm{H}), 1.72-1.58(\mathrm{~m}, 3 \mathrm{H}), 1.46(\mathrm{~s}, 3 \mathrm{H}), 1.15$ (s, 3H). ${ }^{13} \mathrm{C} \mathrm{NMR}\left(100 \mathrm{MHz}, \mathrm{CDCl}_{3}\right): \delta 202.27$, $171.60,171.17,165.88,149.89,148.40,146.11,143.62,139.45,128.56,125.28,124.90$, $114.43,108.58,106.57,101.66,74.86,72.64,64.08,53.76,52.05,51.40,43.38,42.15$, 38.19, 35.48, 30.81, 18.16, 16.44, 15.27. HRESIMS (m/z): $[\mathrm{M}+\mathrm{H}]^{+}$calculated for $\mathrm{C}_{31} \mathrm{H}_{33} \mathrm{O}_{10}$, 565.2029; found, 565.2057. HPLC $t_{\mathrm{R}}=23.401 \mathrm{~min}$; purity $=98.06 \%$.

2-O-(2"-Nitrocinnamoyl)salvinorin B (5h): According to general procedure B, the title compound $\mathbf{5 h}(16 \mathrm{mg}, 71 \%)$ was afforded as a white solid from $\mathbf{3}$ and 2-nitrocinnamic acid. mp 195-197 ${ }^{\circ} \mathrm{C} ;{ }^{1} \mathrm{H}$ NMR $\left(400 \mathrm{MHz}, \mathrm{CDCl}_{3}\right): \delta 8.21(\mathrm{~d}, J=16.0 \mathrm{~Hz}, 1 \mathrm{H}), 8.06(\mathrm{~d}, J=8.0$ $\mathrm{Hz}, 1 \mathrm{H}), 7.68-7.66(\mathrm{~m}, 2 \mathrm{H}), 7.59-7.56(\mathrm{~m}, 1 \mathrm{H}), 7.42(\mathrm{~s}, 1 \mathrm{H}), 7.39(\mathrm{~s}, 1 \mathrm{H}), 6.46(\mathrm{~d}, J=16.0$ $\mathrm{Hz}, 1 \mathrm{H}), 6.39$ (s, 1H), $5.53(\mathrm{dd}, J=5.2,11.4 \mathrm{~Hz}, 1 \mathrm{H}), 5.31(\mathrm{dd}, J=7.6,12.6 \mathrm{~Hz}, 1 \mathrm{H}), 3.74$ (s, 3H), $2.82(\mathrm{dd}, J=8.6,8.6 \mathrm{~Hz}, 1 \mathrm{H}), 2.52(\mathrm{dd}, J=5.2,13.4 \mathrm{~Hz}, 1 \mathrm{H}), 2.42-2.36(\mathrm{~m}, 2 \mathrm{H})$, 
$2.26(\mathrm{~s}, 1 \mathrm{H}), 2.16-2.09(\mathrm{~m}, 2 \mathrm{H}), 1.82(\mathrm{ddd}, J=3.0,3.0,10.4 \mathrm{~Hz}, 1 \mathrm{H}), 1.70-1.56(\mathrm{~m}, 3 \mathrm{H})$, 1.46 (s, 3H), 1.15 (s, 3H). ${ }^{13} \mathrm{C}$ NMR $\left(100 \mathrm{MHz}, \mathrm{CDCl}_{3}\right): \delta 201.82,171.47,171.07,164.52$, 148.36, 143.73, 141.55, 139.48, 133.56, 130.61, 130.19, 129.17, 125.17, 121.83, 108.44, 75.45, 72.07, 64.07, 53.57, 52.00, 51.38, 43.31, 42.19, 38.18, 35.45, 30.87, 18.18, 16.47, 15.23. HRESIMS (m/z): $[\mathrm{M}+\mathrm{H}]^{+}$calculated for $\mathrm{C}_{30} \mathrm{H}_{32} \mathrm{NO}_{10}, 566.1951$; found, 566.1989. HPLC $t_{\mathrm{R}}=21.901 \mathrm{~min}$; purity $=96.93 \%$.

2-O-(4"-Nitrocinnamoyl)salvinorin B (5i): According to the general procedure B, the title compound $\mathbf{5 i}$ (13 $\mathrm{mg}, 59 \%)$ was yielded as a white solid from $\mathbf{3}$ and 4-nitrocinnamic acid. $\mathrm{mp} 217-219^{\circ} \mathrm{C} ;{ }^{1} \mathrm{H}$ NMR $\left(400 \mathrm{MHz}, \mathrm{CDCl}_{3}\right): \delta 8.27(\mathrm{~d}, J=8.0 \mathrm{~Hz}, 1 \mathrm{H}), 7.80(\mathrm{~d}, J=16.0$ $\mathrm{Hz}, 1 \mathrm{H}), 7.70(\mathrm{~d}, J=8.0 \mathrm{~Hz}, 2 \mathrm{H}), 7.43(\mathrm{~s}, 1 \mathrm{H}), 7.41(\mathrm{~s}, 1 \mathrm{H}), 6.65(\mathrm{~d}, J=16.0 \mathrm{~Hz}, 1 \mathrm{H}), 6.40$ (s, 1H), $5.54(\mathrm{dd}, J=5.2,11.4 \mathrm{~Hz}, 1 \mathrm{H}), 5.31(\mathrm{dd}, J=7.6,12.6 \mathrm{~Hz}, 1 \mathrm{H}), 3.75(\mathrm{~s}, 3 \mathrm{H}), 2.82$ (dd, $J=8.6,8.6 \mathrm{~Hz}, 1 \mathrm{H}), 2.53(\mathrm{dd}, J=5.2,13.4 \mathrm{~Hz}, 1 \mathrm{H}), 2.44-2.38(\mathrm{~m}, 2 \mathrm{H}), 2.25(\mathrm{~s}, 1 \mathrm{H})$, 2.18-2.09 (m, 2H), 1.83 (ddd, $J=3.0,3.0,10.4 \mathrm{~Hz}, 1 \mathrm{H}), 1.72-1.56(\mathrm{~m}, 3 \mathrm{H}), 1.47$ (s, 3H), 1.16 (s, 3H). ${ }^{13} \mathrm{C} \mathrm{NMR}\left(100 \mathrm{MHz}, \mathrm{CDCl}_{3}\right): \delta 201.81,171.51,171.06,164.83,148.65$, $143.75,143.19,140.66,139.37,128.66,125.14,124.16,120.78,108.41,75.52,71.99$, 64.16, 53.60, 52.05, 51.41, 43.36, 42.15, 38.18, 35.42, 30.78, 18.16, 16.48, 15.16. HRESIMS (m/z): [M+Na] $]^{+}$calculated for $\mathrm{C}_{30} \mathrm{H}_{31} \mathrm{NO}_{10} \mathrm{Na}, 588.1987$; found, 588.1951. HPLC $t_{\mathrm{R}}=33.586 \mathrm{~min}$; purity $=98.73 \%$.

2-O-(2"-Trifluoromethylcinnamoyl)salvinorin B (5j): According to general procedure B, the title compound $\mathbf{5 j}$ (14 $\mathrm{mg}, 62 \%$ ) was obtained as a white solid from $\mathbf{3}$ and 2trifluoromethylcinnamic acid. $\mathrm{mp} 208-210{ }^{\circ} \mathrm{C} ;{ }^{1} \mathrm{H} \mathrm{NMR}\left(400 \mathrm{MHz}, \mathrm{CDCl}_{3}\right): \delta 8.14(\mathrm{~d}, J=$ $16.0 \mathrm{~Hz}, 1 \mathrm{H}), 7.75-7.70(\mathrm{~m}, 2 \mathrm{H}), 7.58-7.55(\mathrm{~m}, 1 \mathrm{H}), 7.54-7.52(\mathrm{~m}, 1 \mathrm{H}), 7.42(\mathrm{~s}, 1 \mathrm{H}), 7.40$ $(\mathrm{s}, 1 \mathrm{H}), 6.51(\mathrm{~d}, J=16.0 \mathrm{~Hz}, 1 \mathrm{H}), 6.39(\mathrm{~s}, 1 \mathrm{H}), 5.52(\mathrm{dd}, J=5.2,11.4 \mathrm{~Hz}, 1 \mathrm{H}), 5.30(\mathrm{dd}, J=$ 7.6, $12.6 \mathrm{~Hz}, 1 \mathrm{H}), 3.74(\mathrm{~s}, 3 \mathrm{H}), 2.81(\mathrm{dd}, J=8.6,8.6 \mathrm{~Hz}, 1 \mathrm{H}), 2.52(\mathrm{dd}, J=5.2,13.4 \mathrm{~Hz}$, $1 \mathrm{H}), 2.42-2.37(\mathrm{~m}, 2 \mathrm{H}), 2.27(\mathrm{~s}, 1 \mathrm{H}), 2.19-2.09(\mathrm{~m}, 2 \mathrm{H}), 1.82(\mathrm{ddd}, J=3.0,3.0,10.4 \mathrm{~Hz}$, $1 \mathrm{H}), 1.70-1.58(\mathrm{~m}, 3 \mathrm{H}), 1.46$ (s, 3H), $1.14(\mathrm{~s}, 3 \mathrm{H}) .{ }^{13} \mathrm{C} \mathrm{NMR}\left(100 \mathrm{MHz}, \mathrm{CDCl}_{3}\right): \delta 201.90$, $171.58,171.15,164.82,143.62,141.65,139.55,132.97,132.10,129.83,127.97,126.24$, 125.20, 121.01, 108.50, 75.34, 72.08, 64.02, 53.54, 51.89, 51.33, 43.30, 42.15, 38.11, 35.53, 30.80, 18.16, 16.43, 15.14. HRESIMS (m/z): $[\mathrm{M}+\mathrm{H}]^{+}$calculated for $\mathrm{C}_{31} \mathrm{H}_{32} \mathrm{~F}_{3} \mathrm{O}_{8}, 589.1971$; found, 589.1996. HPLC $t_{\mathrm{R}}=42.336 \mathrm{~min}$; purity $=98.04 \%$.

2-O-(4"-Trifluoromethylcinnamoyl)salvinorin B (5k): According to general procedure B, the title compound $\mathbf{5 k}$ (12 $\mathrm{mg}, 60 \%$ ) was obtained as a white solid from $\mathbf{3}$ and 4trifluoromethylcinnamic acid. mp 148-150 $\left.{ }^{\circ} \mathrm{C} ;{ }^{1} \mathrm{H} \mathrm{NMR} \mathrm{(400} \mathrm{MHz,} \mathrm{CDCl}_{3}\right): \delta 7.77(\mathrm{~d}, J=$ $16.0 \mathrm{~Hz}, 1 \mathrm{H}), 7.68-7.63(\mathrm{~m}, 4 \mathrm{H}), 7.42(\mathrm{~s}, 1 \mathrm{H}), 7.40(\mathrm{~s}, 1 \mathrm{H}), 6.60(\mathrm{~d}, J=16.0 \mathrm{~Hz}, 1 \mathrm{H}), 6.39$ (s, 1H), $5.54(\mathrm{dd}, J=5.2,11.4 \mathrm{~Hz}, 1 \mathrm{H}), 5.31(\mathrm{dd}, J=7.6,12.6 \mathrm{~Hz}, 1 \mathrm{H}), 3.75(\mathrm{~s}, 3 \mathrm{H}), 2.82$ $(\mathrm{dd}, J=8.6,8.6 \mathrm{~Hz}, 1 \mathrm{H}), 2.53(\mathrm{dd}, J=5.2,13.4 \mathrm{~Hz}, 1 \mathrm{H}), 2.42-2.36(\mathrm{~m}, 2 \mathrm{H}),, 2.25(\mathrm{~s}, 1 \mathrm{H})$, 2.15-2.05 (m, 2H), $1.82(\mathrm{ddd}, J=3.0,3.0,10.4 \mathrm{~Hz}, 1 \mathrm{H}), 1.69-1.58(\mathrm{~m}, 3 \mathrm{H}), 1.47(\mathrm{~s}, 3 \mathrm{H})$, 1.16 (s, 3H). ${ }^{13} \mathrm{C} \mathrm{NMR}\left(100 \mathrm{MHz}, \mathrm{CDCl}_{3}\right): \delta 201.83,171.54,171.09,165.22,144.43$, $143.70,139.45,137.45,128.35,125.23,119.36,108.40,75.32,71.99,64.15,53.52,52.02$, $51.37,43.42,42.16,38.21,35.52,30.89,18.22,16.46,15.22 . \operatorname{HRESIMS}(\mathrm{m} / \mathrm{z}):[\mathrm{M}+\mathrm{Na}]^{+}$ calculated for $\mathrm{C}_{31} \mathrm{H}_{31} \mathrm{~F}_{3} \mathrm{O}_{8} \mathrm{Na}, 611.1893$; found, 611.1867. HPLC $t_{\mathrm{R}}=52.609$ min; purity $=$ $97.79 \%$. 
2-O-[2",5"-bis(Trifluoromethyl)cinnamoyl]salvinorin B (5l): According to general procedure $\mathrm{B}$, the title compound $\mathbf{5 l}$ (17 $\mathrm{mg}, 66 \%)$ was afforded as a white solid from $\mathbf{3}$ and 2,5-di(trifluoromethyl)cinnamic acid. mp $185-187{ }^{\circ} \mathrm{C} ;{ }^{1} \mathrm{H}$ NMR $\left(400 \mathrm{MHz}, \mathrm{CDCl}_{3}\right): \delta 8.11$ $(\mathrm{d}, J=16.0 \mathrm{~Hz}, 1 \mathrm{H}), 7.98(\mathrm{~s}, 1 \mathrm{H}), 7.86(\mathrm{~d}, J=8.0 \mathrm{~Hz}, 1 \mathrm{H}), 7.76(\mathrm{~d}, J=8.0 \mathrm{~Hz}, 1 \mathrm{H}), 7.42$ (s, $1 \mathrm{H}), 7.40(\mathrm{~s}, 1 \mathrm{H}), 6.59(\mathrm{~d}, J=16.0 \mathrm{~Hz}, 1 \mathrm{H}), 6.39(\mathrm{~s}, 1 \mathrm{H}), 5.52(\mathrm{dd}, J=5.2,11.4 \mathrm{~Hz}, 1 \mathrm{H})$, $5.30(\mathrm{dd}, J=7.6,12.6 \mathrm{~Hz}, 1 \mathrm{H}), 3.74(\mathrm{~s}, 3 \mathrm{H}), 2.82(\mathrm{dd}, J=8.6,8.6 \mathrm{~Hz}, 1 \mathrm{H}), 2.52(\mathrm{dd}, J=$ 5.2, 13.4 Hz, 1H), 2.42-2.37 (m, 2H), 2.27 (s, 1H), 2.21-2.13 (m, 2H), 1.83 (ddd, $J=3.0$, 3.0, $10.4 \mathrm{~Hz}, 1 \mathrm{H}), 1.71-1.58(\mathrm{~m}, 3 \mathrm{H}), 1.46(\mathrm{~s}, 3 \mathrm{H}), 1.15(\mathrm{~s}, 3 \mathrm{H}) .{ }^{13} \mathrm{C}$ NMR $(100 \mathrm{MHz}$, $\left.\mathrm{CDCl}_{3}\right): \delta 201.62,171.46,171.48,164.34,143.71,140.00,134.24,130.83,128.79,127.12$, $125.20,123.01,122.29,108.43,75.55,72.01,64.10,53.46,51.99,51.34,43.23,42.15$, $38.15,35.49,30.79,18.15,16.40,15.13$. HRESIMS (m/z): $[\mathrm{M}+\mathrm{H}]^{+}$calculated for $\mathrm{C}_{32} \mathrm{H}_{31} \mathrm{~F}_{6} \mathrm{O}_{8}, 657.1818$; found, 657.1803. HPLC $t_{\mathrm{R}}=71.301 \mathrm{~min}$; purity $=98.95 \%$.

2-O-[3'-(3"-Pyridyl)acryloyl]salvinorin B (5m): According to general procedure B, the compound $\mathbf{5 m}$ (13 mg, 63\%) was obtained as a white solid from 3 and trans 3-(3pyridyl)acrylic acid. mp $189-191{ }^{\circ} \mathrm{C} ;{ }^{1} \mathrm{H}$ NMR (400 MHz, $\left.\mathrm{CDCl}_{3}\right): \delta 8.77$ (s, 1H), $8.62(\mathrm{~d}, J$ $=8.0 \mathrm{~Hz}, 1 \mathrm{H}), 7.88(\mathrm{~d}, J=8.0 \mathrm{~Hz}, 1 \mathrm{H}), 7.75\left(\mathrm{~d}, J=16.0 \mathrm{~Hz},{ }^{1} \mathrm{H}\right), 7.41-7.37(\mathrm{~m}, 2 \mathrm{H}), 6.60$ $(\mathrm{d}, J=16.0 \mathrm{~Hz}, 1 \mathrm{H}), 6.38(\mathrm{~s}, 1 \mathrm{H}), 5.52(\mathrm{dd}, J=5.2,11.4 \mathrm{~Hz}, 1 \mathrm{H}), 5.31(\mathrm{dd}, J=7.6,12.6 \mathrm{~Hz}$, $1 \mathrm{H}), 3.74(\mathrm{~s}, 3 \mathrm{H}), 2.82(\mathrm{dd}, J=8.6,8.6 \mathrm{~Hz}, 1 \mathrm{H}), 2.53(\mathrm{dd}, J=5.2,13.4 \mathrm{~Hz}, 1 \mathrm{H}), 2.42-2.37$ $(\mathrm{m}, 2 \mathrm{H}), 2.26(\mathrm{~s}, 1 \mathrm{H}), 2.18-2.11(\mathrm{~m}, 2 \mathrm{H}), 1.82(\mathrm{ddd}, J=3.0,3.0,10.4 \mathrm{~Hz}, 1 \mathrm{H}), 1.68-1.57$ (m, 3H), 1.46 (s, 3H), 1.15 (s, 3H). $\left.{ }^{13} \mathrm{C} \mathrm{NMR} \mathrm{(100} \mathrm{MHz,} \mathrm{CDCl}_{3}\right): \delta 201.93,171.49,171.10$, $165.11,150.88,149.52$, 143.61, 142.35, 139.50, 134.67, 129.91, 125.19, 123.86, 119.13, 108.32, 75.37, 72.01, 63.84, 53.41, 51.77, 51.21, 43.35, 41.90, 37.96, 35.49, 30.65, 18.01, 16.29, 15.20. HRESIMS (m/z): $[\mathrm{M}+\mathrm{H}]^{+}$calculated for $\mathrm{C}_{29} \mathrm{H}_{32} \mathrm{NO}_{8}, 522.2083$; found, 522.2069. HPLC $t_{\mathrm{R}}=10.043 \mathrm{~min}$; purity $=97.11 \%$.

2-O-[3'-(3"-Thiophenyl)acryloyl]salvinorin B (5n): According to general procedure B, the compound 5n (15 mg, 67\%) was yielded as a white solid from 3 and 3-thiopheneacrylic acid. mp 184-186 ${ }^{\circ} \mathrm{C} ;{ }^{1} \mathrm{H} \mathrm{NMR}\left(400 \mathrm{MHz}, \mathrm{CDCl}_{3}\right): \delta 7.75(\mathrm{~d}, J=16.4 \mathrm{~Hz}, 1 \mathrm{H}), 7.53(\mathrm{~s}$, $1 \mathrm{H}), 7.42$ (s, 1H), 7.40 (s, 1H), 7.35-7.32 (m, 2H), 6.39 (s, 1H), 6.35 (d, J=16.4 Hz, 1H), $5.54(\mathrm{dd}, J=5.2,11.4 \mathrm{~Hz}, 1 \mathrm{H}), 5.29(\mathrm{dd}, J=7.6,12.6 \mathrm{~Hz}, 1 \mathrm{H}), 3.74(\mathrm{~s}, 3 \mathrm{H}), 2.80$ (dd, $J=$ 8.6, 8.6 Hz, 1H), 2.54 (dd, $J=5.2,13.4 \mathrm{~Hz}, 1 \mathrm{H}), 2.42-2.38$ (m, 2H), 2.23 (s, 1H), 2.19-2.08 $(\mathrm{m}, 2 \mathrm{H}), 1.82(\mathrm{ddd}, J=3.0,3.0,10.4 \mathrm{~Hz}, 1 \mathrm{H}), 1.68-1.57(\mathrm{~m}, 3 \mathrm{H}), 1.47(\mathrm{~s}, 3 \mathrm{H}), 1.15$ (s, $3 \mathrm{H}) .{ }^{13} \mathrm{C} \mathrm{NMR}\left(100 \mathrm{MHz}, \mathrm{CDCl}_{3}\right): \delta 202.21,171.51,171.14,165.78,143.69,139.78$, 139.58, 137.03, 128.73, 127.11, 124.89, 116.55, 108.56, 75.03, 71.82, 64.04, 53.63, 51.97, $51.45,43.40,42.15,35.54,30.84,18.25,16.44,15.06$. HRESIMS (m/z): $[\mathrm{M}+\mathrm{H}]^{+}$calculated for $\mathrm{C}_{28} \mathrm{H}_{31} \mathrm{O}_{8} \mathrm{~S}, 527.1661$; found, 527.1637. HPLC $t_{\mathrm{R}}=23.444 \mathrm{~min}$; purity $=97.02 \%$.

\subsection{Pharmacology}

\subsubsection{Affinity Determinations: HEK293T-KOR Membrane Preparation and Radioligand Binding Assay}

HEK293T membrane preparation: Cells stably expressing $\kappa$-opioid receptors (HEK293TKOR) were plated in 15-cm dishes (in DMEM containing 10\% FBS) and grown to $90 \%$ confluence [10]. Cells were then washed with PBS at $\mathrm{pH} 7.4$, and harvested by scraping into PBS, pH 7.4. Harvested cells were centrifuged at $1,000 \times \mathrm{g}$ for $10 \mathrm{~min}$ and subsequently 
hypotonically lysed by resuspension into ice-cold binding buffer $(50 \mathrm{mM}$ Tris-HCl, $10 \mathrm{mM}$ $\mathrm{MgCl}_{2} 0.1 \mathrm{mM}$ EDTA, $\mathrm{pH}$ 7.4). Membranes were isolated by centrifugation at $21,000 \times \mathrm{g}$ for $20 \mathrm{~min}$. The supernatant was removed and the membrane pellets were stored at $-80{ }^{\circ} \mathrm{C}$ until used for radioligand binding assays.

4.3.2. Radioligand binding assay-Membranes prepared as above were resuspended in binding buffer to $1 \mu \mathrm{g}$ protein $/ \mu \mathrm{L}$ (measured by Bradford assay using BSA as standard), and $50 \mu \mathrm{L}$ was added to each well of a polypropylene 96-well plate containing $200 \mu \mathrm{L}$ binding buffer with $0.5 \mathrm{nM}\left[{ }^{3} \mathrm{H}\right] \mathrm{U}-69593$, and reference or test ligands at various concentrations ranging from $10 \mathrm{pM}$ to $10 \mu \mathrm{M}$ (final concentrations). After $1.5 \mathrm{~h}$ incubation in the dark at room temperature, the reactions were harvested onto 0.3\% PEI-soaked Filtermax GF/A filters (Wallac) and washed three times with ice-cold $50 \mathrm{mM}$ Tris, $\mathrm{pH}$ 7.4, using a PerkinElmer Filtermate 96-well harvester. The filters were subsequently dried and placed on a hot plate $\left(100^{\circ} \mathrm{C}\right.$ ), and Melitilex-A (Wallac) scintillant was applied. The filters were then removed from the hot plate and allowed to cool. The filters were counted on a Wallac TriLux MicroBeta counter (3 min/well). Residual [ $\left.{ }^{3} \mathrm{H}\right] \mathrm{U}-69593$ binding to filtered membranes was plotted as a function of $\log$ [ligand] and the data were regressed using the one-site competition model built into Prism 4.0 (GraphPad software).

4.3.3. cAMP Inhibition: KOR-Mediated cAMP Assay-HEK293T cells were cotransfected with plasmids encoding the cAMP biosensor GloSensor-22F (Promega) and hKOR receptor. After $18 \mathrm{~h}$ incubation at $37^{\circ} \mathrm{C}$ the cells were seeded $(20,000$ cells $/ 20 \mu \mathrm{L} /$ well) into white, clear-bottom, 384 well tissue culture plates in HBSS, 10\% FBS, $20 \mathrm{mM}$ HEPES, pH 7.4. After a 1- to 2-h recovery, cells were treated with $10 \mu \mathrm{L}$ of $3 \times$ test or reference drug prepared in HBSS, 10\% FBS, 20 mM HEPES, pH 7.4. After 30 min, cAMP production was stimulated and detected by treatment with $10 \mu \mathrm{L}$ of $1,200 \mathrm{nM}(4 \times)$ isoproterenol in 8\% (4×) GloSensor reagent. Luminescence per well per second was read on a Wallac TriLux MicroBeta plate counter. Data were normalized to the isoproterenol response (0\%) and the maximal Salvinorin A-induced inhibition thereof (100\%) and regressed using the sigmoidal dose-response function built into GraphPad Prism 4.0.

\subsection{Molecular Modeling}

Molecular modeling investigations were conducted using the SYBYL-X molecular modeling package (version 2.0, 2012, Tripos Associates, St. Louis, MO). GOLDSuite 5.1 (Cambridge Crystallographic Data Centre, Cambridge, UK) was employed to perform automated docking tasks. Default parameters were used unless otherwise noted. The molecular modeling methods employed here are analogous to those previously published (see $\mathrm{Wu}$, et al.,[9] Vardy, et al.[28] and references within).

The structure of the hKOR was prepared for docking by extracting the 'B' chain (protein only) from the PDB file (PDB ID $=4 \mathrm{DJH}$ ) and adding hydrogen atoms, and extracting the JDTic ligand. Five water molecules $(1307,1311,1313,1314,1316)$ located in the 'B' chain binding site were also extracted and saved individually for use in the docking exercises. The structure of the mMOR was prepared for docking in an analogous fashion by extracting the 'A' chain from PDB ID $=4 \mathrm{DJH}$. As there is no difference in the amino acid composition of 
the hMOR and mMOR in the orthosteric binding site, the compounds were docked into the 4DJH structure. The structures of the compounds to be docked were sketched in SYBYL and energy-minimized using the Tripos Force Field (Gasteiger-Hückel charges, distancedependent dielectric constant $=4.0$; non-bonded interaction cutoff $=8 \AA$; termination criterion $=$ energy gradient $<0.05 \mathrm{kcal} /(\operatorname{mol} \times \AA)$ or 100,000 iterations $)$.

GOLD 5.1 flexible docking was performed without constraints for all ligands. GoldScore was used as the scoring/fitness function. For each receptor, a binding site definition consisting of a 15- $\AA$ radius sphere around the $\mathrm{D}(3.32) \mathrm{C}^{\beta}$ atom was employed. Water molecules were toggled on or off as required, with 10 solutions generated for each run. To more fully explore potential binding modes for the docked compounds, the Diverse Solutions option in GOLD was enabled with the cluster size set to 1 and $1.5 \AA$ RMSD. The final receptor-ligand complex for each ligand was chosen interactively by selecting the highest-scoring pose that was consistent with experimentally-derived information about the binding mode of the ligand. The chosen solution(s) were then merged back into the receptor structure, along with any necessary water molecules. Finally, the complexes were energyminimized in SYBYL using the TFF with the previously-stated parameters. The stereochemical quality of the final models was assessed using PROCHECK.

All computations were performed on quad-core Intel Xeon-based SGI Virtu VS (CentOS 6.1), AMD Opteron-based Hewlett-Packard xw9400 (CentOS 6.1) and 8-core Intel Xeonbased Mac Pro (OS-X 10.6 Snow Leopard) workstations.

\section{Supplementary Material}

Refer to Web version on PubMed Central for supplementary material.

\section{Acknowledgments}

This work was supported by the NIH Grant R01 DA017204 and the NIMH Psychoactive Drug Screening Program (PDSP), University of North Carolina at Chapel Hill, NC 27599 (BLR). The authors wish to thank Dr. Daneel Ferreira for thorough review and editing the manuscript. The authors are also thankful to Dr. Bin Wang and Dr. Avula Bharathi for their assistance with HRESIMS. Finally, we would also like to thank Dr. Richard Westkaemper for many useful discussions.

\section{References}

1. Ortega A, Blount JF, Manchand PS. Salvinorin, a new trans-neoclerodane diterpene from Salvia divinorum (Labiatae). J Chem Soc Perkins Trans. 1982; 1:2505-2508.

2. Roth BL, Baner K, Westkaemper RB, Siebert D, Rice KC, Steinberg S, Ernsberger P, Rothman RB, Salvinorin A. A potent naturally occurring nonnitrogenous $\kappa$ opioid selective agonist. Proc Natl Acad Sci U S A. 2002; 99:11934-11939. [PubMed: 12192085]

3. Cunningham CW, Rothman RB, Prisinzano TE. Neuropharmacology of the naturally occurring $\kappa-$ opioid hallucinogen salvinorin A. Pharmacol Rev. 2011; 63:316-347. [PubMed: 21444610]

4. Fichna J, Lewellyn K, Yan F, Roth BL, Zjawiony JK. Synthesis and biological evaluation of new salvinorin A analogues incorporating natural amino acids. Bioorg Med Chem Lett. 2011; 21:160163. [PubMed: 21115248]

5. Lovell KM, Prevatt-Smith KM, Lozama A, Prisinzano TE. Synthesis of neoclerodane diterpenes and their pharmacological effects. Top Curr Chem. 2011; 299:141-185. [PubMed: 21630517] 
6. Lozama A, Cunningham CW, Caspers MJ, Douglas JT, Dersch CM, Rothman RB, Prisinzano TE. Opioid receptor probes derived from cycloaddition of the hallucinogen natural product salvinorin $\mathrm{A}$. J Nat Prod. 2011; 74:718-726. [PubMed: 21338114]

7. Polepally PR, White K, Vardy E, Roth BL, Ferreira D, Zjawiony JK. Kappaopioid receptorselective dicarboxylic ester-derived salvinorin A ligands. Bioorg Med Chem Lett. 2013; 23:28602862. [PubMed: 23587424]

8. Prisinzano TE. Neoclerodanes as atypical opioid receptor ligands. 2012 David W. Robertson Award for Excellence in Medicinal Chemistry. J Med Chem. 2013; 56:3435-3443. [PubMed: 23548164]

9. Wu H, Wacker D, Mileni M, Katritch V, Han GW, Vardy E, Liu W, Thompson AA, Huang X-P, Carroll FI, Mascarella SW, Westkaemper RB, Mosier PD, Roth BL, Cherezov V, Stevens RC. Structure of the human K-opioid receptor in complex with JDTic. Nature. 2012; 485:327-332. [PubMed: 22437504]

10. Yan F, Bikbulatov RV, Mocanu V, Dicheva N, Parker CE, Wetsel WC, Mosier PD, Westkaemper RB, Allen JA, Zjawiony JK, Roth BL. Structure-based design, synthesis, and biochemical and pharmacological characterization of novel salvinorin A analogues as active state probes of the $\kappa-$ opioid receptor. Biochemistry. 2009; 48:6898-6908. [PubMed: 19555087]

11. Amslinger $S$. The tunable functionality of $\alpha, \beta$-unsaturated carbonyl compounds enables their differential application in biological systems. ChemMedChem. 2010; 5:351-356. [PubMed: 20112330]

12. Cheng C-Y, Wu S-C, Hsin L-W, Tam SW. Selective reversible and irreversible ligands for the $\kappa$ opioid receptor. J Med Chem. 1992; 35:2243-2247. [PubMed: 1319495]

13. Koolpe GA, Nelson WL, Gioannini TL, Angel L, Simon EJ. Diastereomeric 6-desoxy-6-spiro-amethylene- $\gamma$-butyrolactone derivatives of naltrexone and oxymorphone. Selective irreversible inhibition of naltrexone binding in an opioid receptor preparation by a conformationally restricted Michael acceptor ligand. J Med Chem. 1984; 27:1718-1723. [PubMed: 6209395]

14. Pitha J, Szabo L, Szurmai Z, Buchowiecki W, Kusiak JW. Alkylating prazosin analogue: Irreversible label for $a_{1}$-adrenoceptors. J Med Chem. 1989; 32:96-100. [PubMed: 2535878]

15. Singh J, Petter RC, Baillie TA, Whitty A. The resurgence of covalent drugs. Nat Rev Drug Discovery. 2011; 10:307-317.

16. Avonto C, Taglialatela-Scafati O, Pollastro F, Minassi A, Di Marzo V, De Petrocellis L, Appendino G. An NMR spectroscopic method to identify and classify thioltrapping agents: Revival of Michael acceptors for drug discovery? Angew Chem Int Ed Engl. 2011; 50:467-471. [PubMed: 21132828]

17. Chu W, Rothfuss J, d'Avignon A, Zeng C, Zhou D, Hotchkiss RS, Mach RH. Isatin sulfonamide analogs containing a Michael addition acceptor: A new class of caspase 3/7 inhibitors. J Med Chem. 2007; 50:3751-3755. [PubMed: 17585855]

18. Couch RD, Browning RG, Honda T, Gribble GW, Wright DL, Sporn MB, Anderson AC. Studies on the reactivity of CDDO, a promising new chemopreventive and chemotherapeutic agent: Implications for a molecular mechanism of action. Bioorg Med Chem Lett. 2005; 15:2215-2219. [PubMed: 15837296]

19. Shi B, Greaney MF. Reversible Michael addition of thiols as a new tool for dynamic combinatorial chemistry. Chem Commun. 2005:886-888.

20. Tidgewell K, Groer CE, Harding WW, Lozama A, Schmidt M, Marquam A, Heimstra J, Partilla JS, Dersch CM, Rothman RB, Bohn LM, Prisinzano TE. Herkinorin analogues with differential $\beta$ arrestin-2 interactions. J Med Chem. 2008; 51:2421-2431. [PubMed: 18380425]

21. Harding WW, Tidgewell K, Byrd N, Cobb H, Dersch CM, Butelman ER, Rothman RB, Prisinzano TE. Neoclerodane diterpenes as a novel scaffold for $\mu$ opioid receptor ligands. J Med Chem. 2005; 48:4765-4771. [PubMed: 16033256]

22. Tidgewell K, Harding WW, Schmidt M, Holden KG, Murry DJ, Prisinzano TE. A facile method for the preparation of deuterium labeled salvinorin A: Synthesis of $\left[2,2,2-{ }^{2} \mathrm{H}_{3}\right]$-salvinorin A. Bioorg Med Chem Lett. 2004; 14:5099-5102. [PubMed: 15380207]

23. Arkoudis E, Stratakis M. Synthesis of cordiaquinones B, C, J, and K on the basis of a bioinspired approach and the revision of the relative stereochemistry of cordiaquinone C. J Org Chem. 2008; 73:4484-4490. [PubMed: 18498197] 
24. Truce WE, Bailey PS Jr. The mechanism of alcoholysis of carboxylic acid halides in the presence of triethylamine. J Org Chem. 1969; 34:1341-1345.

25. Yan F, Mosier PD, Westkaemper RB, Stewart J, Zjawiony JK, Vortherms T, Sheffler DJ, Roth BL. Identification of the molecular mechanisms by which the diterpenoid salvinorin A binds to $\kappa-$ opioid receptors. Biochemistry. 2005; 44:8643-8651. [PubMed: 15952771]

26. Katritch V, Cherezov V, Stevens RC. Diversity and modularity of G proteincoupled receptor structures. Trends Pharmacol Sci. 2012; 33:17-27. [PubMed: 22032986]

27. Negri A, Rives M-L, Caspers MJ, Prisinzano TE, Javitch JA, Filizola M. Discovery of a novel selective kappa-opioid receptor agonist using crystal structure-based virtual screening. J Chem Inf Model. 2013; 53:521-526. [PubMed: 23461591]

28. Vardy E, Mosier PD, Frankowski KJ, Wu H, Katritch V, Westkaemper RB, Aubé J, Stevens RC, Roth BL. Chemotype-selective modes of action of $\kappa$-opioid receptor agonists. J Biol Chem. 2013; 288:34470-34483. [PubMed: 24121503]

29. Ballesteros JA, Weinstein H. Integrated methods for the construction of threedimensional models and computational probing of structure-function relationships in Gprotein coupled receptors. Methods Neurosci. 1995; 25:366-428.

30. Kutrzeba LM, Karamyan VT, Speth RC, Williamson JS, Zjawiony JK. In vitro studies on metabolism of salvinorin A. Pharm Biol. 2009; 47:1078-1084.

\section{Abbreviations used}

$\begin{array}{ll}\text { DOR } & \delta \text {-opioid receptor } \\ \text { GPCR } & \text { G protein-coupled receptor } \\ \text { KOR } & \text { א-opioid receptor } \\ \text { MOR } & \mu \text {-opioid receptor } \\ \text { TM } & \text { transmembrane } \\ \text { PDB } & \text { Protein Data Bank }\end{array}$




\section{Highlights}

$>\quad$ New potential Michael acceptor analogues of salvinorin A were synthesized.

$>\quad$ Compounds were evaluated for binding affinity at $\kappa-, \delta$-, and $\mu$-opioid receptors.

$>\quad$ Molecular modeling studies describe putative binding modes for the compounds.

$>\quad$ Most compounds have high binding affinity at $\kappa ; \mathbf{5 a}$ has dual affinity for $\kappa$ and $\mu$.

$>\quad 5 a$ could be developed as a potent CNS or peripheral drug in the near future. 

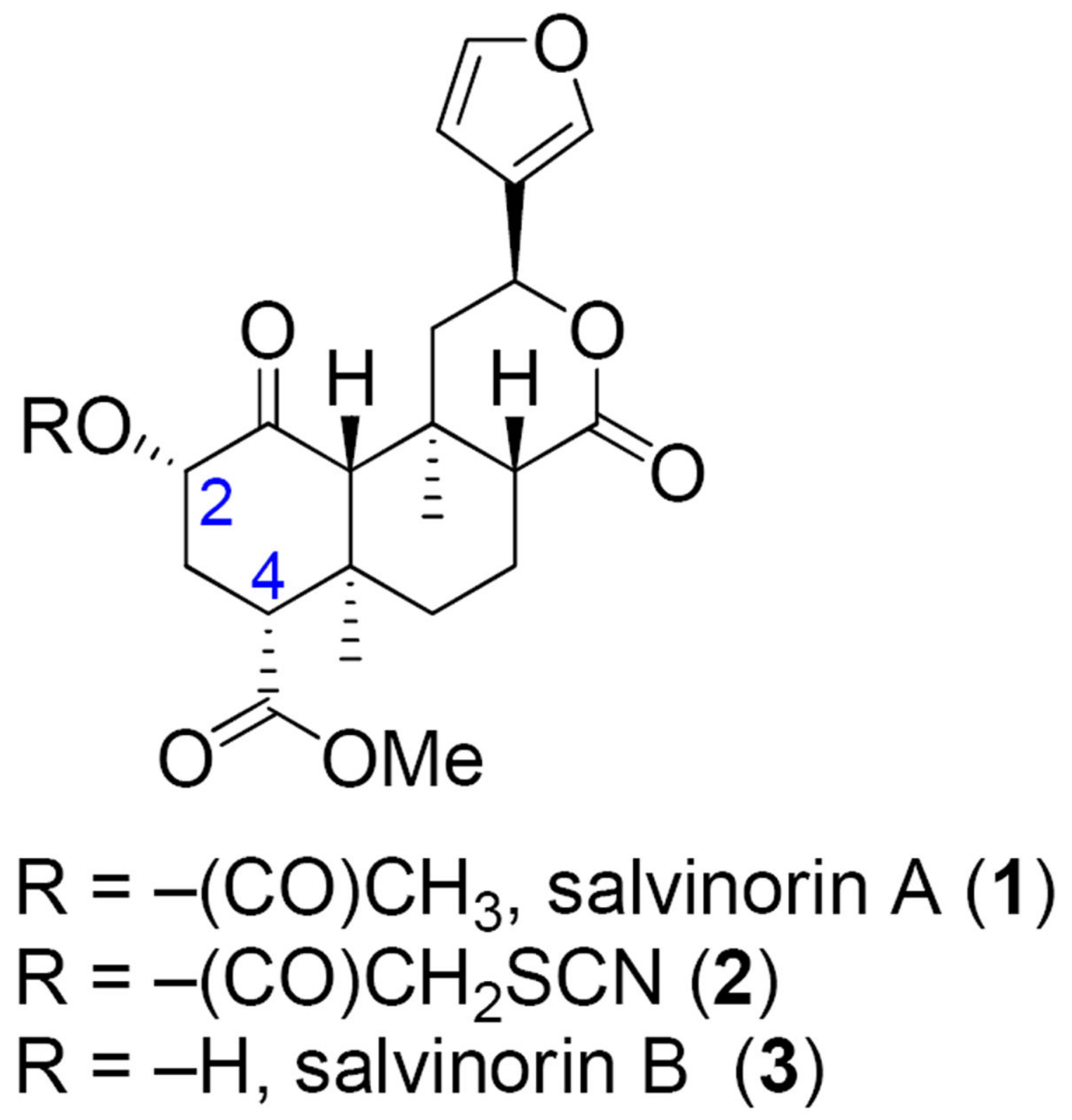

Figure 1.

The structures of salvinorin A (1), 22-thiocyanatosalvinorin A (RB-64; 2) and salvinorin B (3). 


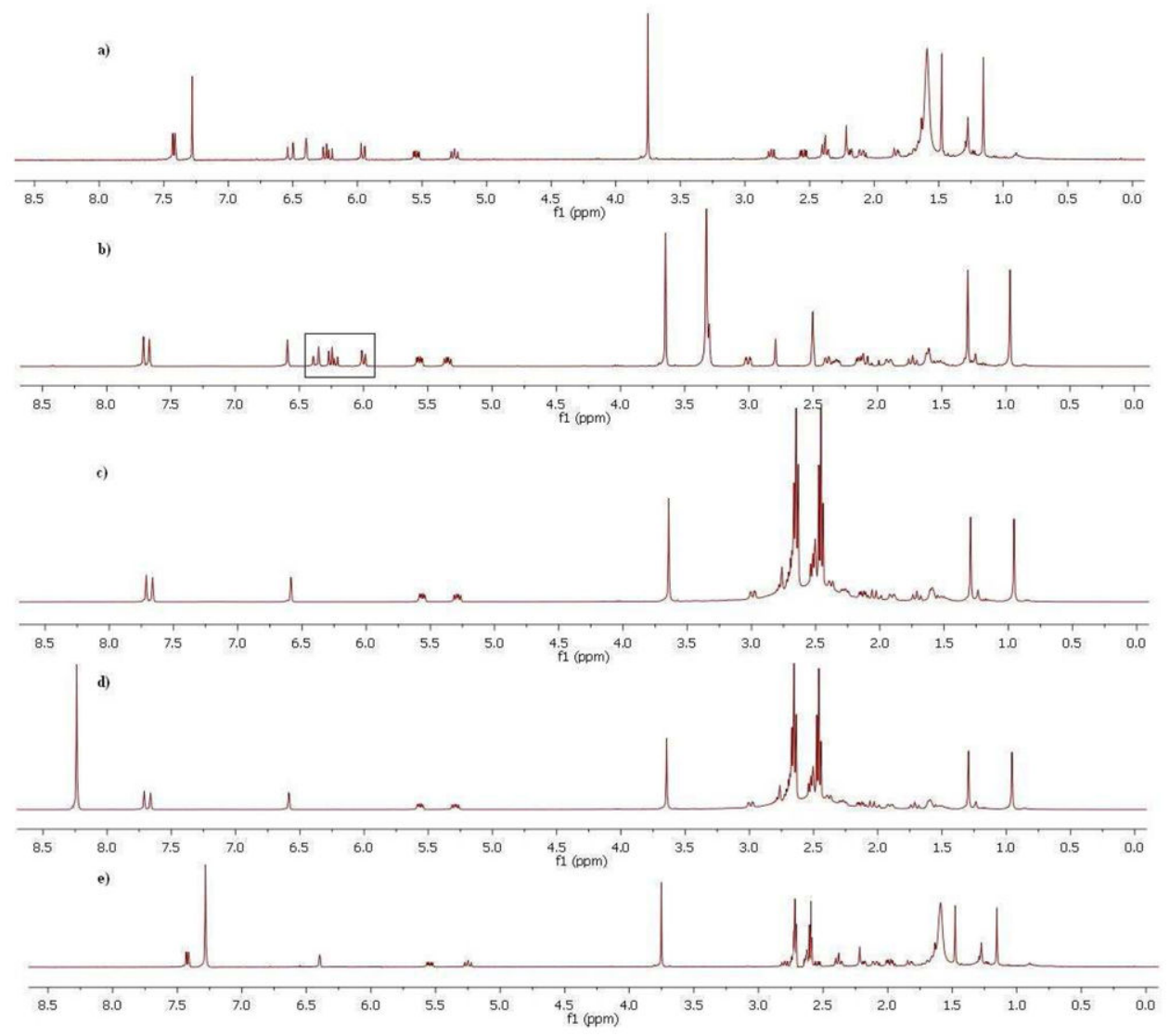

Figure 2.

a) The ${ }^{1} \mathrm{H}$ NMR spectrum of $\mathbf{4 a}$ in $\mathrm{CDCl}_{3}$. b) The ${ }^{1} \mathrm{H}$ NMR spectrum of $\mathbf{4 a}$ in DMSO- $d_{6}$. c) The ${ }^{1} \mathrm{H}$ NMR spectrum of compound $\mathbf{4 a}$ in DMSO- $d_{6}$ after the addition of cysteamine (note disappearance of the olefin proton resonances). d) The ${ }^{1} \mathrm{H}$ NMR spectrum of the reaction mixture (acrylate derivative + cysteamine + DMSO- $d_{6}$ ) after dilution with $\mathrm{CDCl}_{3}$ (sample locked in DMSO- $\left.d_{6}\right)$. e) ${ }^{1} \mathrm{H}$ NMR spectrum of the reaction mixture after dilution with $\mathrm{CDCl}_{3}$ (sample locked in $\mathrm{CDCl}_{3}$ ). 

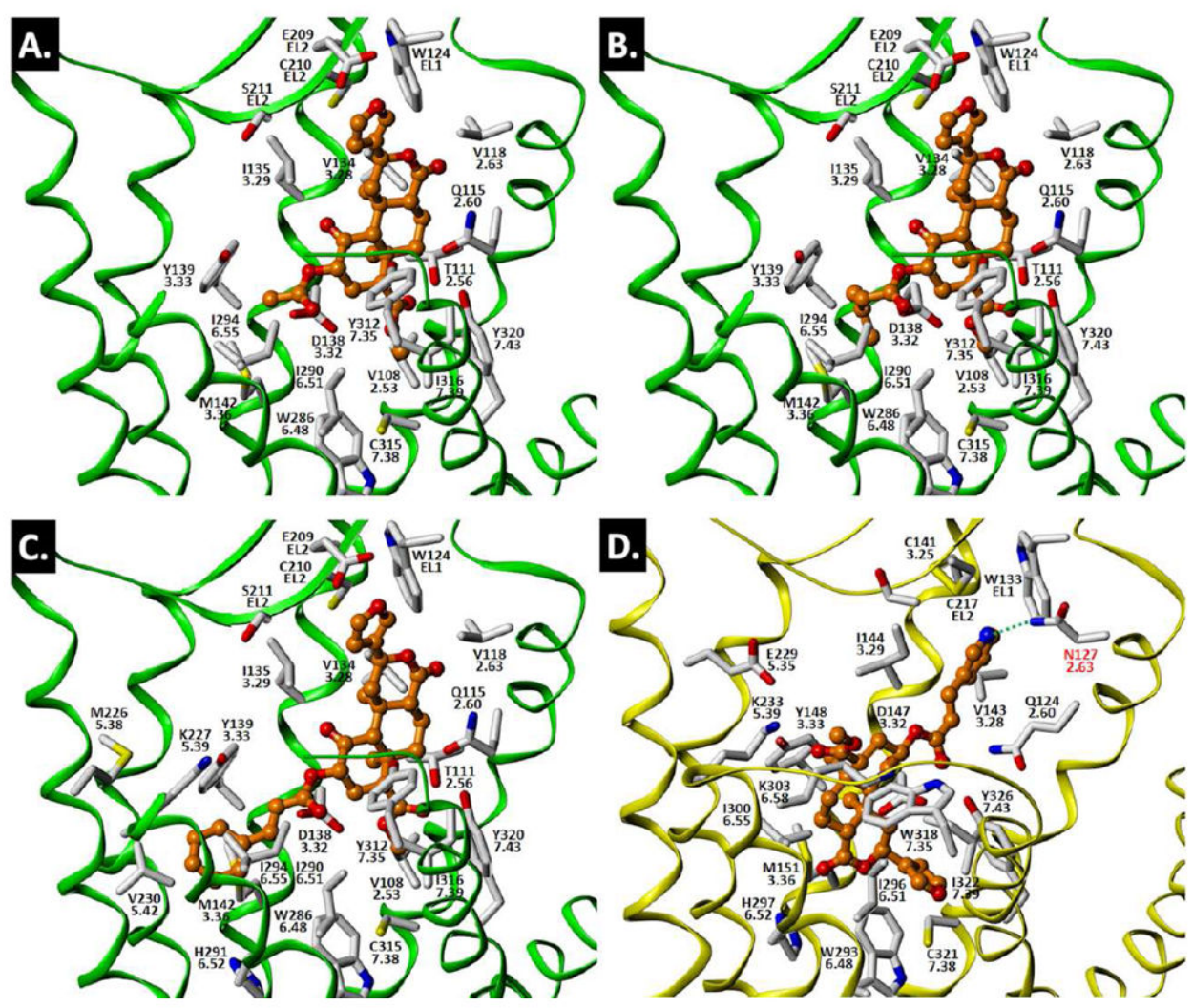

Figure 3.

Putative binding mode for compounds a) 1, b) 4d, c) 5a and d) $\mathbf{5 m}$. 


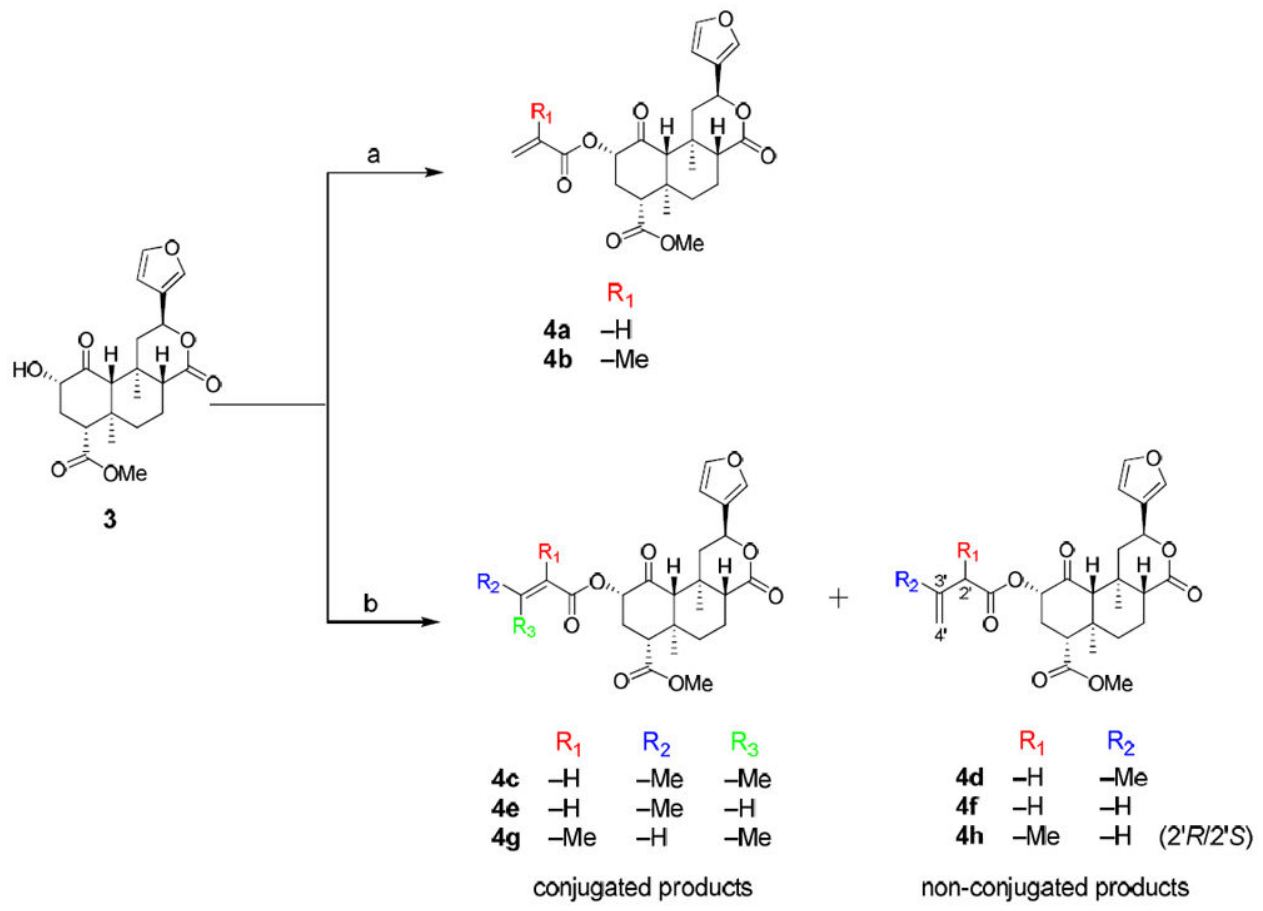

Scheme 1.

Reagents and Conditions: (a) acryloyl chloride or methacryloyl chloride, $\mathrm{Et}_{3} \mathrm{~N}$, dry DCM, 0 ${ }^{\circ} \mathrm{C} \rightarrow \mathrm{rt}, 3 \mathrm{~h}$. (b) 3,3-dimethylacryloyl chloride or crotonyl chloride or 2,3-dimethylacryloyl chloride, $\mathrm{Et}_{3} \mathrm{~N}$, dry DCM, $0{ }^{\circ} \mathrm{C} \rightarrow \mathrm{rt}, 3 \mathrm{~h}$. 

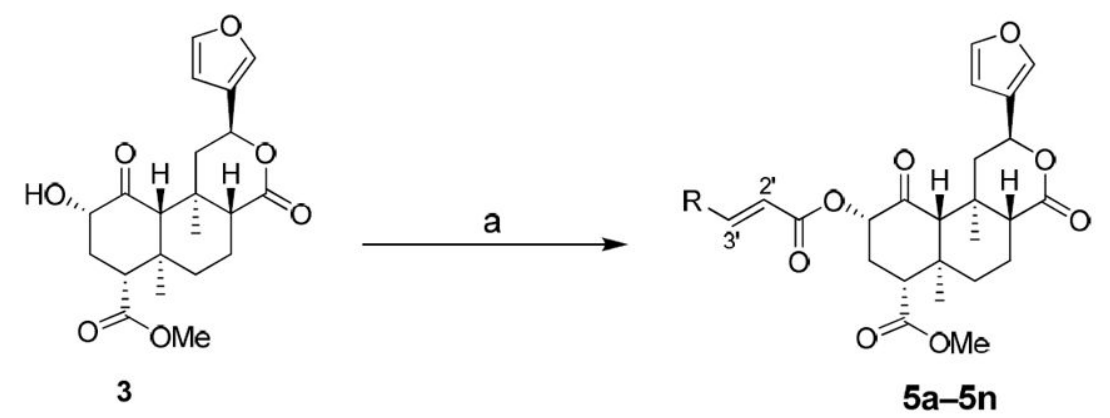

$\mathrm{R}=\mathrm{C}_{\mathrm{R}_{4}}^{\mathrm{R}_{2}}$

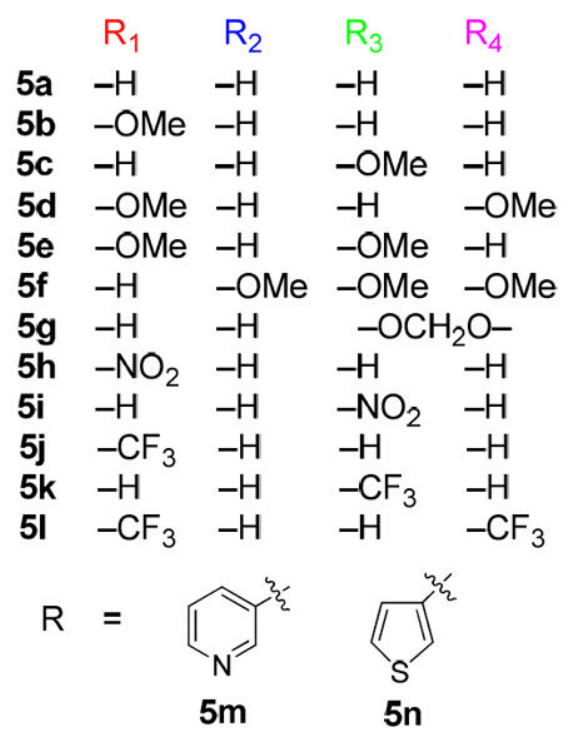

Scheme 2.

Reagents and Conditions: (a) appropriate cinnamic acid or heterocyclic acrylic acid, DCC, DMAP, dry DCM, rt, 2-5 h. 


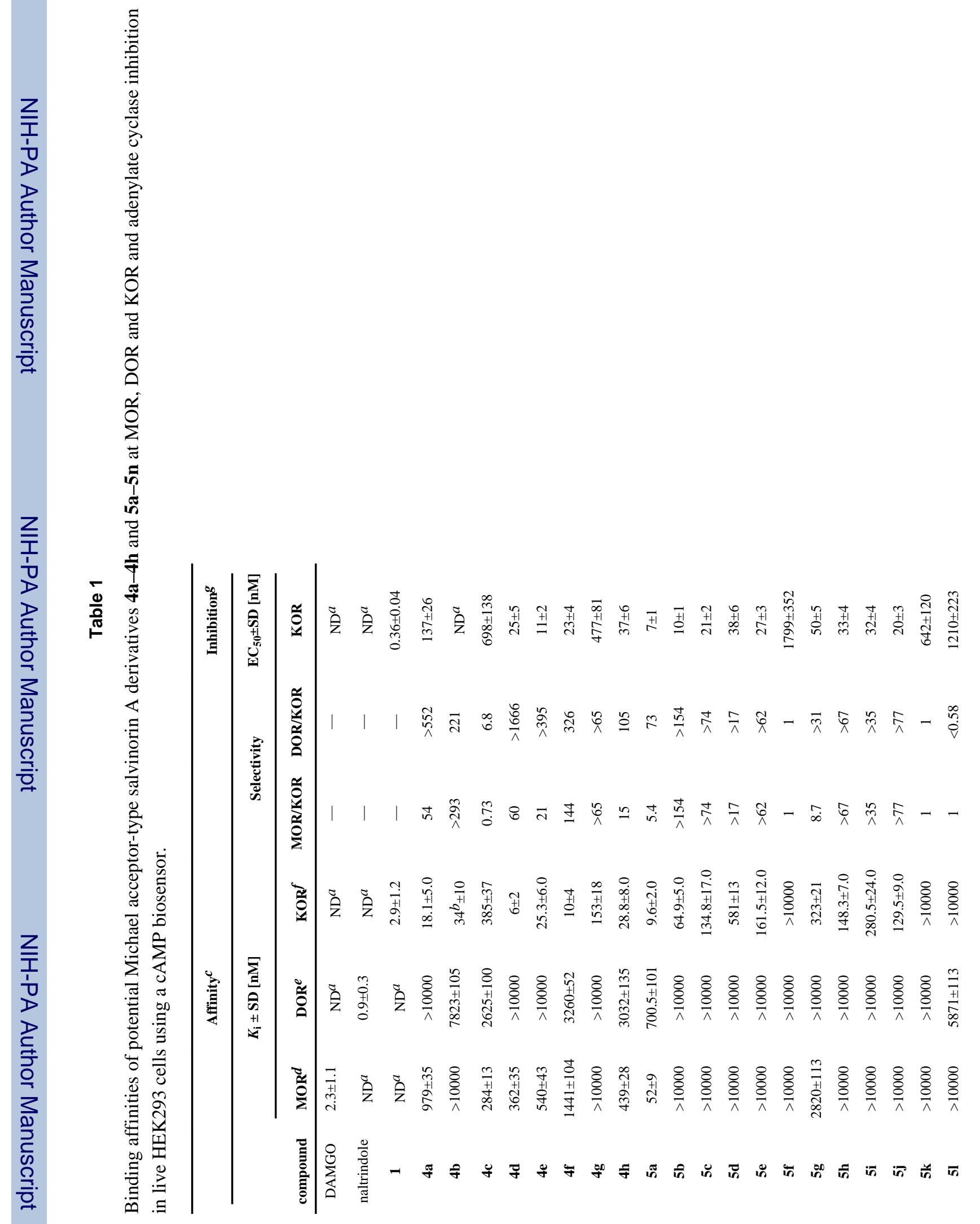




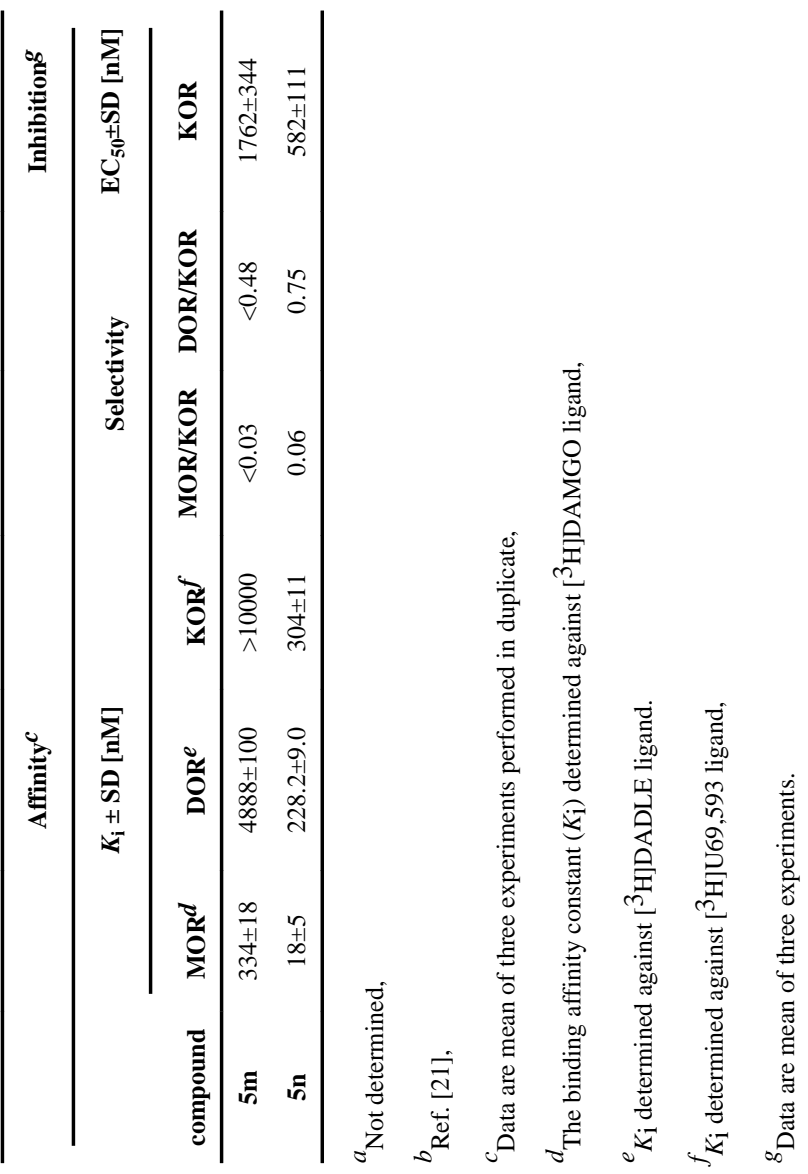

